DOI: $10.20472 /$ IAC.2019.045.040

\author{
SHIVANI TANEJA \\ University of Essex , United Kingdom
}

\title{
GENDER GAP IN JOB UTILITY OF BRITISH WORKERS
}

\begin{abstract}
:
The gender gap in attaining a university qualification has gradually narrowed in Britain and this has motivated the evaluation of gender differences in non-pecuniary returns of education. Therefore, this paper explores the trends in job utility of workers, measured by subjective self-evaluation of satisfaction scores from work. The data shows that while female workers experience higher job utility compared to men during the survey period, male workers are reporting higher utility in recent years, resulting in narrowing gender gap in job utility. Logistic regression models are used to understand the factors contributing to this gender gap. The results suggest that education is unlikely to contribute to this trend whereas unemployment has a small contribution to the emerging pattern. Furthermore, the results show that job utility of male workers is more cyclically sensitive compared to female workers as stalling unemployment during an economic downturn affects men more than women.
\end{abstract}

\section{Keywords:}

Job satisfaction, Unemployment, United Kingdom 


\section{Introduction}

The gender gap in attaining a university qualification has not only gradually narrowed over the years in Britain, but there is a sudden reversal and a new gender gap is seen with girls outperforming boys and gaining an advantage in educational achievements. According to the Higher Education Statistics Authority data, 55\% of those enrolled in a full-time undergraduate degree in 2010-11 were females compared to $45 \%$ males. Some of the factors contributing to this increase in the proportion of women attaining a post-secondary qualification include efforts made by policy-makers to improve female education, women's position in the labour market and women's desire to be economically independent. Investments in human capital allow individuals to attain a position in the labour market and contribute to their hourly wage and productivity. Consequently, utility derived from work is also affected. Hence, an investment in higher education yields monetary benefits, such as a wage increase and better employability prospects. On the other hand, non-monetary benefits, such as welfare and other dimensions that are not part of the monetary returns are likely to be affected. Some economist also point out social returns to higher education, benefitting other members of the society through positive externalities, such as teamwork (Gemmell, 1997). While the financial returns of education are well explained in the economic literature, quantifying its effect on labour market outcomes (see Blundell et al., 2000; Blanchflower and Oswald, 1994), this paper sheds some light on the gender gap in non-monetary returns of post-secondary schooling, examining trends in job utility as measure by subjective self-evaluation of satisfaction scores from work of British workers. From a worker's perspective, satisfaction from work is important in understanding the decision-making process on labour market participation and mobility. On the other hand, employers benefit from maximising welfare in order to achieve efficiency. Therefore, utility from work is of great interest to employers, social scientists and policy makers.

A graphical representation of the data from 1991-2008 shows a narrowing gender gap in job utility of British workers (see Section 2). Therefore, this paper seeks to address the following questions: why is male utility from work increasing and catching up to women's higher scores? Are changes in economic status, i.e. having no spells in unemployment in period $\mathrm{t}-2$ to experiencing job losses in $\mathrm{t}-1$ affecting current job utility? And are men suffering more due to stalling unemployment during an economic downturn?

This paper is structured as follows. Section 2 provides an overview of the existing literature on subjective indicators of job satisfaction, life satisfaction and other measure of wellbeing. The data source and variables of interest are described in Section 3 and Section 4 points out the estimation methodology. Section 5 presents the empirical results. In particular, the determinants of job utility as measured by satisfaction from work are explored in subsection 5.1 to identify factors responsible for the catch-up, using logit regressions. Subsection 5.2 presents the results from fixed 
effect logit regression technique. Additionally, regression results in subsection 5.3 show the effect of frequent changes in economic status in three consecutive time periods, i.e. having no spells in unemployment in period t-2 to experiencing job losses in $\mathrm{t}-1$ is evaluated on current job utility. Furthermore, in order to understand if business cycles can explain gender differences in job utility trends, subsection 5.4 shows changes in frequent transition in economic activity and unemployment spells during the recession. Section 6 draws the conclusion.

\section{Economics of individual utility}

While job satisfaction is a subject of popular attention in psychology and sociology literature, one of the early studies in economics was by Freeman (1978), stressing that these subjective variables convey valuable information about the economic life of a worker and are important determinants of labour market mobility. Workers reporting higher satisfaction levels compared to others are less likely to quit their present jobs. Since then, numerous studies have focused on the determinants of job satisfaction. For example, Clark (1996) investigated the effect of a wide range of personal and employment-related characteristics and among the many variables controlled for, the role of education is particularly interesting. This is because of its negative relationship confirming that workers with higher educational qualifications tend to be more dissatisfied. The explanation given was that, although higher educated workers have better jobs; the process of education increases their expectations, thereby resulting in low satisfaction levels. Furthermore, Clark (1997) analysed gender differences in job satisfaction in Britain and concluded that women experience higher satisfaction than men because of lower expectations from their job and not because their jobs are better than those of men. He concluded that once gender differentials in job expectations are narrowed, the satisfaction differential also disappear, for example, for the young, higher educated, professional and those in male dominated workplaces.

Bardasi and Francesconi (2004) explored the effect of atypical employment on job satisfaction as well as its effect on life satisfaction, mental health and general health status. Their results indicate that job satisfaction is lower for seasonal as well as casual workers and higher for workers in part-time employment. Booth and Van Ours (2008) studied the relationship between part-time work and happiness of British partnered couples, as measured by job satisfaction, hours-of-work satisfaction and life satisfaction. It was concluded that men working full-time without working overtime have the highest hours-of-work satisfaction, although their job and life satisfaction remains unaffected. And British women working part-time experience higher job and hours satisfaction while their life satisfaction remains unaffected. 
Unemployment is considered to be one of the important determinants of wellbeing. It is associated with a loss in income as well loss in non-monetary benefits, such as selfesteem, social connections and overall wellbeing (Clark et al., 2010). Clark and Oswald (1994) showed a negative correlation between unemployment and wellbeing scores, as measured by General Health Questionnaire (GHQ). Winkelmann and Winkelmann (1998) found that unemployment is associated with a greater loss in life satisfaction than the loss in labour income. Not only have studies traced out the relationship between own unemployment and own wellbeing, but previous studies have also underlined the effect of other's unemployment on individual wellbeing. For example, Clark (2003) measured other's unemployment rate at regional, household and couple level and showed that an individual's utility is negatively correlated with higher unemployment rates among other individuals. In other words, using GHQ scores as a proxy for utility and unemployment rates (between individuals and over time) as a proxy for social norms, the results confirmed that higher unemployment rate of others tend to lower wellbeing of the employed. And the wellbeing of unemployed individuals increases with higher unemployment rates. The literature has also analysed psychological impacts of past unemployment and its scarring effect on individual wellbeing. Clark et al. (2001) used German data from 1984-94 and found that currently employed individuals with higher unemployment rates are more likely to report lower life satisfaction, suggesting unemployment scars. Their results confirmed that this scarring effect is stronger for men than for women. They also studied the effect of persistent unemployment and found that unemployment hurts less for those unemployed individuals experiencing higher levels of unemployment in the past. And lastly, economists have explored the macroeconomics of welfare, analysing the link between aggregate variables and wellbeing. For example Di Tella et al. (2001) analysed the effect of aggregate unemployment and inflation on life satisfaction and found evidence that happiness negatively correlates with percentage of joblessness and price change. Similar results were found by Oswald (1997).

Thus, numerous studies have explored the determinants and their corresponding correlations with wellbeing, using various measures. The goal of this paper is not to study the determinants of job utility but to analyse the gender gap in job utility and explore the factors contributing to the trend. To the best of my knowledge, no previous studies have analysed the factors responsible for the emerging job utility trends of British workers, although numerous studies have looked into the determinants of job satisfaction.

\section{Data}

Data for the empirical estimation uses all eighteen waves of the British Household Panel Survey (BHPS), covering the period of 1991-2008. The BHPS gathers information on a nationally representative random sample of private households in 
Britain. Interviews were first conducted in 1991 and carried annually until 2008. A wide range of information on individual and employment-related characteristics is available and controlled for in the analysis.

The estimating sample includes all individuals aged 18 to 60 reported to be currently employed at the time of the survey. To focus on non-monetary benefits of postsecondary education, respondents below 18 years of age are dropped from the analysis. This is because under the British educational system, schooling is free and compulsory between the ages of 5 and 16 . Subsequently, students can continue for a period of two years in secondary schooling, with the aim of entering university after completing 13 years of full-time education. Attaining a vocational qualification is also an option. Alternatively, individuals who do not wish to continue academic study can get employed and enter the labour force. Since one of the goals of this paper is to understand if job utility trends for both men and women are affected by the new gender gap in post-secondary educational achievements, the sample is restricted to individuals aged 18 and over. The sample also drops individuals above 60 years of age. ${ }^{1}$ This yields an unbalanced panel, with 7623 men and 8240 women $(41,585$ and 45,616 person-wave observations for men and women respectively). Table 1 presents the descriptive statistics for both men and women.

\begin{tabular}{|l|c|c|c|c|}
\hline $\begin{array}{l}\text { Table 1: Descriptive } \\
\text { statistics }\end{array}$ & Men & Men & Women & Women \\
\hline Variables & Mean & $\begin{array}{c}\text { Standard } \\
\text { Deviation }\end{array}$ & Mean & $\begin{array}{c}\text { Standard } \\
\text { Deviation }\end{array}$ \\
\hline High job satisfaction & 0.7801 & 0.41 & 0.8407 & 0.37 \\
\hline MSc/Phds & 0.0382 & 0.19 & 0.0269 & 0.16 \\
\hline University first degree & 0.1416 & 0.35 & 0.1405 & 0.35 \\
\hline Vocational & 0.0899 & 0.29 & 0.0756 & 0.26 \\
\hline School qualification & 0.5782 & 0.49 & 0.5921 & 0.49 \\
\hline No qualification & 0.1522 & 0.36 & 0.1649 & 0.37 \\
\hline Unemployment spell & 0.0605 & 0.24 & 0.0415 & 0.20 \\
\hline Year of birth & 63.1946 & 11.75 & 62.9976 & 11.82 \\
\hline
\end{tabular}

\footnotetext{
1 The retirement age at the time of the survey was 65 years for men and 60 years for women. To minimise heterogeneity, all individuals older than 60 years of age are dropped.
} 


\begin{tabular}{|l|c|c|c|c|}
\hline & & & & \\
\hline Year of birth squared & 0.9409 & 0.24 & 0.9440 & 0.23 \\
\hline UK born & 0.9934 & 0.08 & 0.9927 & 0.09 \\
\hline Small Firm & 0.4236 & 0.49 & 0.5165 & 0.50 \\
\hline Working hours & 0.9472 & 0.22 & 0.6125 & 0.49 \\
\hline Manager & 0.1818 & 0.39 & 0.1106 & 0.31 \\
\hline Professional & 0.1000 & 0.30 & 0.1028 & 0.30 \\
\hline Technical & 0.1082 & 0.31 & 0.1339 & 0.34 \\
\hline Clerical & 0.0975 & 0.30 & 0.2567 & 0.44 \\
\hline Craft & 0.1777 & 0.38 & 0.0189 & 0.14 \\
\hline Personal & 0.0691 & 0.25 & 0.1636 & 0.37 \\
\hline Sales & 0.0523 & 0.22 & 0.1073 & 0.31 \\
\hline Plant and machinery & 0.1402 & 0.35 & 0.0334 & 0.18 \\
\hline Unskilled & 0.0732 & 0.26 & 0.0728 & 0.26 \\
\hline No health problems & 0.5546 & 0.50 & 0.4608 & 0.50 \\
\hline Promotion & & & & \\
\hline Job tenure & 0.5457 & 0.50 & 0.4775 & 0.50 \\
\hline Second job & 4.5061 & 6.18 & 3.9621 & 5.27 \\
\hline Private firm & 0.0808 & 0.27 & 0.0967 & 0.30 \\
\hline Civil service & 0.7924 & 0.41 & 0.5903 & 0.49 \\
\hline Local government & 0.0445 & 0.21 & 0.0408 & 0.20 \\
\hline Other public & 0.0470 & 0.21 & 0.1219 & 0.33 \\
\hline Non profit & 0.0198 & 0.14 & 0.0465 & 0.21 \\
\hline Age & 37.2 & 127.2 & 37.5 & 127.5 \\
\hline Age-Squared & 868.70 & 1533.6727 & 868.70 \\
\hline & & & & \\
\hline
\end{tabular}




\begin{tabular}{|l|c|c|c|c|}
\hline Married & 0.7131 & 0.45 & 0.7069 & 0.46 \\
\hline Separated & 0.0504 & 0.22 & 0.1033 & 0.30 \\
\hline Single & 0.2365 & 0.42 & 0.1897 & 0.39 \\
\hline Children & 0.6937 & 0.99 & 0.6847 & 0.94 \\
\hline London & 0.0695 & 0.25 & 0.0728 & 0.26 \\
\hline South & 0.2311 & 0.42 & 0.2274 & 0.42 \\
\hline Centre & 0.1757 & 0.38 & 0.1652 & 0.37 \\
\hline NorthWest & 0.0854 & 0.28 & 0.0853 & 0.28 \\
\hline NorthEast & 0.1255 & 0.33 & 0.1214 & 0.33 \\
\hline Wales & 0.1366 & 0.34 & 0.1381 & 0.34 \\
\hline Scotland/N.Ireland & 0.1763 & 0.38 & 0.1899 & 0.39 \\
\hline Income & & & & \\
\hline GDP & 0.9975 & 0.05 & 0.9852 & 0.12 \\
\hline Interest rate & 2.6533 & 1.49 & 2.6548 & 1.48 \\
\hline Observations & 3.0134 & 1.32 & 2.9945 & 1.32 \\
\hline
\end{tabular}

Source: Own calculations based on the BHPS

\section{The dependent variable}

High job utility, as measured by overall high job satisfaction is constructed from responses to the following question, in the Questionnaire: 'All things considered, how satisfied or dissatisfied are you with your present job overall using 1-7 scale?' The response variable takes the value 1 if respondents report a value of 5 and above and 0 otherwise. Figure 1 plots the trends in overall high job satisfaction spanning the period 1991-2008, separately for men and women. As shown, $72.9 \%$ men report an overall high job satisfaction with their current job in 1991, which increases over the years to $82.0 \%$ in 2008 . On the other hand, $81.4 \%$ of women report high job satisfaction in 1991 and this increases to $85.6 \%$ in 2008 . Thus, both men and women report higher satisfaction scores over the years. Women's higher satisfaction scores are not surprising because previous studies have documented higher job utility among 
women relative to men (Clark, 1997). However, it is interesting to witness a considerably large gender gap in the early 1990 s and with time, this gap has gradually narrowed over the years. The proportion of men reporting high job satisfaction is increasing and gradually catching up to the satisfaction levels of female workers over the years. This paper aims to contribute to the existing literature by understanding the factors responsible for this narrowing gap and understand that while job utility is relatively stable for female workers in the more recent years, men are increasingly reporting higher wellbeing. ${ }^{2}$

\section{Figure 1. High job satisfaction}

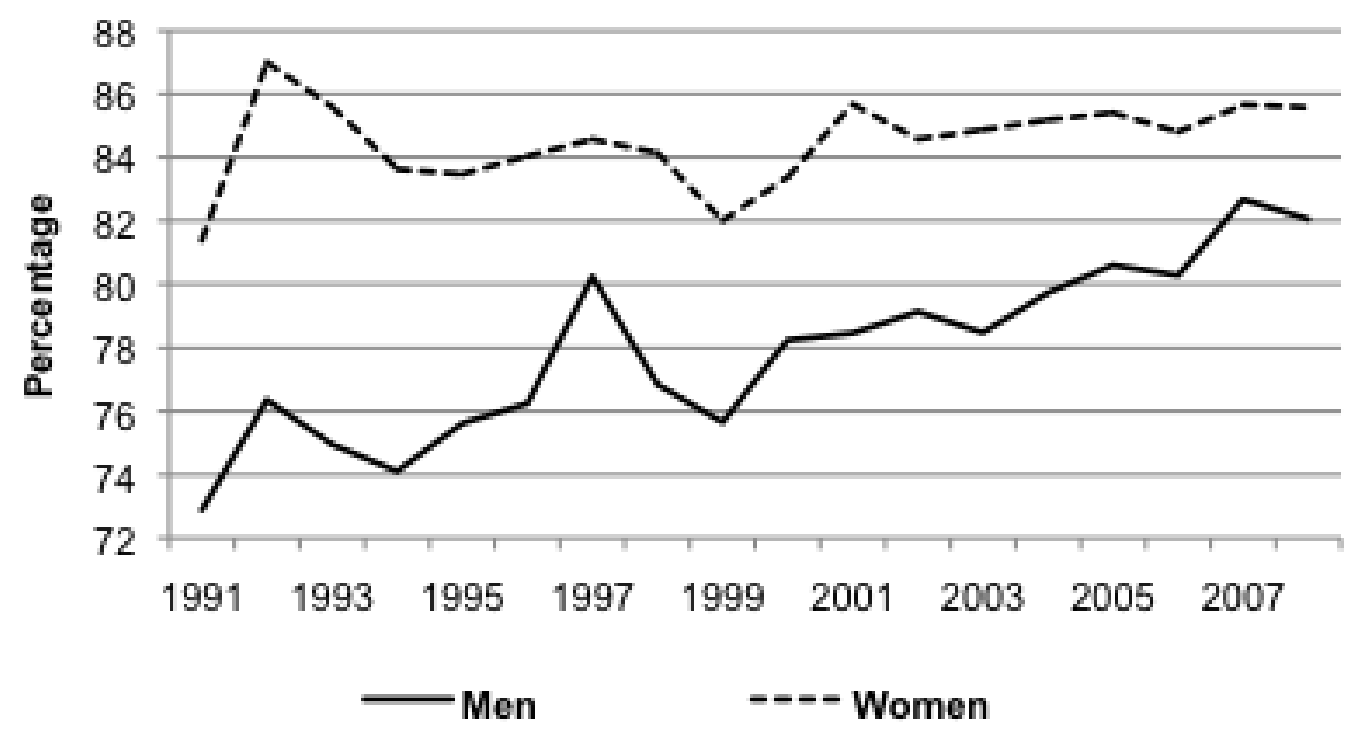

Source: Own calculation based on the BHPS

\section{Variables}

Educational qualifications: The BHPS data reports each individual's highest academic qualification recorded as the following and respondents are allocated to one of the categories: higher degree (MSc and PhD), first degree, $\mathrm{HND} / \mathrm{HNC}$ /teaching, A-levels, O-levels, CSE, none of the above. From this information, the following dummy variables are generated and controlled for in the empirical analysis, (i) MSc and PhD, (ii) university first degree, (iii) vocational qualification. (iv) school qualification, (v) no qualification. Figure 2 plots the trends in percentage of workers with a university first degree as well as higher degrees (respondents with a MSc and PhD degree only are included in higher degrees), separately for men and women. There is an upward trend for both men and women attaining a university degree in Britain. A higher proportion of

\footnotetext{
2 For robustness checks, different cut-off points were also studied, i.e. the dependent variable was high job satisfaction taking the value 1 if respondents report a value of 4 and above and 0 otherwise. A similar pattern to Figure 1 was seen.
} 
men had a university first degree than women in early 1990s and as time progressed, women outperformed men. And attaining higher degrees are more popular among British men; however, gender differences are extremely small.

Figure 2. Post-secondary education

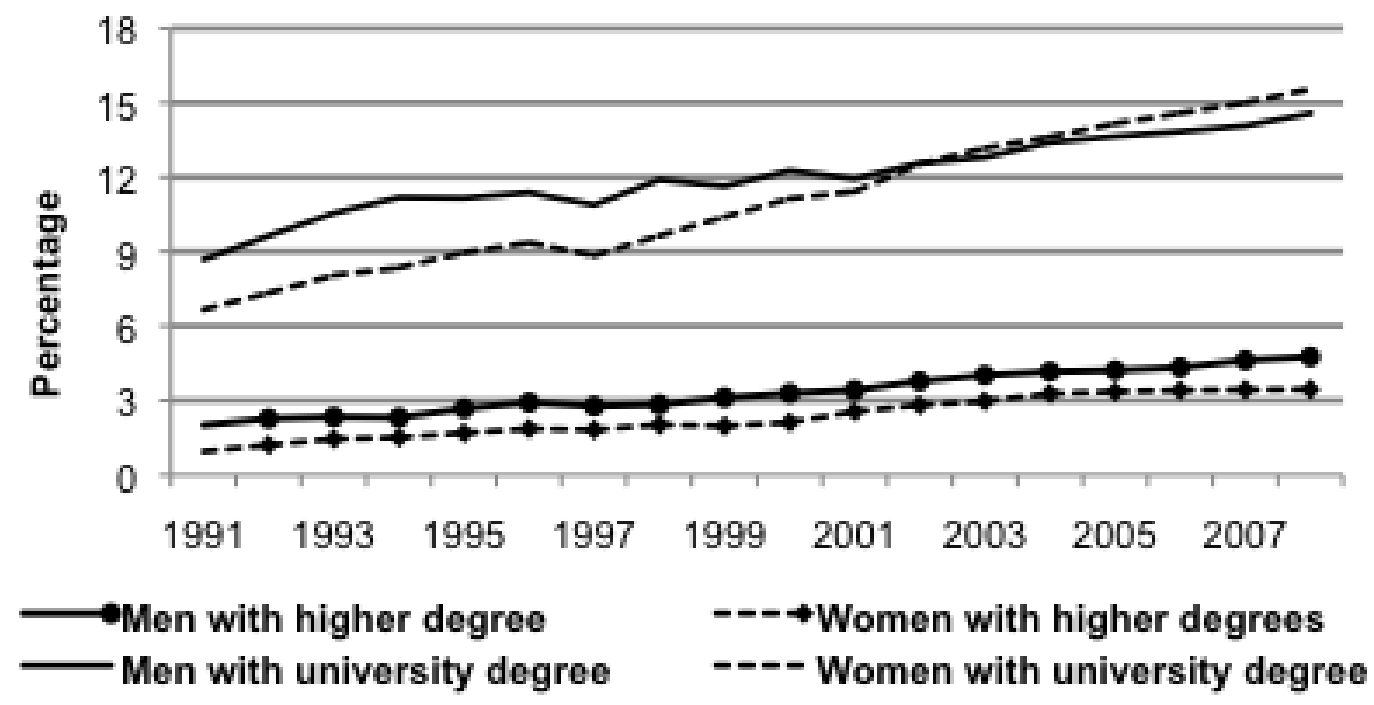

Source: Own calculation based on the BHPS

Unemployment spells: The empirical analysis controls for past unemployment spells experienced by a worker before being employed in the current job. It takes the value 1 if a respondent experienced positive spells in unemployment (ranging from 1 to 4 ) in the year to September 1 and 0 otherwise. Table 2 shows the number of spells recorded in the data for both men and women. A higher proportion of women experience no spells in unemployment whereas job losses are more common among male workers. It is widely known in labour economics that female labour force participation rates are lower than that of men. In other words, there is greater sample selection among female workers because they may opt out of the labour force, especially if they have a preference for household production. And among those women who choose to be active in the labour market, if unhappy with their jobs they are also likely to occupy some other status (Clark, 1997). However, this does not hold for men. As more men are in employment with lower likelihood of opting out, a higher percentage tend to experience job losses and more frequently than women. 


\begin{tabular}{|l|l|l|}
\hline ble 2: Number of Unemployment spells & & \\
\hline & Men (\%) & Women (\%) \\
\hline 0 & 89.78 & 94.25 \\
\hline 1 & 9.18 & 5.31 \\
\hline 2 & 0.95 & 0.4 \\
\hline 3 & 0.08 & 0.04 \\
\hline 4 & 0.01 & 0.01 \\
\hline
\end{tabular}

Source: Own calculation based on BHPS

Employment-related characteristics: The empirical analysis includes a few employment-related characteristics that are likely to influence job utility of British workers. For example, a dummy variable indicating whether or not the individual works in a small firm, employing less than 50 co-workers, is incorporated. In order to control for the number of working hours, a dummy variable takes the value 1 if the respondent worked for 30 hours or more per week is also included. The variable promotion takes value 1 if there are promotion opportunities in the current job. Years of tenure in the current job are also controlled for. The one digit Standard Occupational Classification classifies the occupation of each individual and the categories are managers, professionals, technical, clerical, craft, personal and protective services, sales, plant and machinery operatives and other unskilled occupations. A dummy variable takes the value 1 if the individual has a second job. The employing sector is captured by a set of variables indicating whether the individual works in the private sector, civil service, local government, other public or non-profit organization.

Personal characteristics: The age range of men and women included is 18 to 60 as well as age squared is included in the empirical analysis. Respondents were asked about their marital status and takes the value 1 if the individual is married or living as a couple whereas widowed, divorced or separated respondents are grouped together as separated. And the third category is a dummy variable indicating whether or not the respondent is single. The number of children in the household is also incorporated in the regressions. The health variable specifies whether the respondent has no health problems. Regions of residence are categorised into seven separate dummy variables. Respondent earning more than $£ 100$ as gross monthly income from the present job is also controlled for.

Time-invariant variables: Respondent's year of birth, square of the birth year and place of birth are fixed over time and also controlled for. The year of birth and its square are important time-invariant variables because it makes it possible to understand if there are any generational shifts in job satisfaction. A dummy variable takes the value 1 if the respondent is born in Britain. 
Macroeconomic variables: In order to control for business cycles, aggregate macroeconomic data are drawn from the World Bank database. The World Bank defines the annual GDP growth rate (\%) as the 'annual percentage growth rate of GDP at market prices based on constant local currency. Aggregates are based on constant 2000 U.S. dollars' (World Bank, 2013). The real interest rate is defined as 'the lending interest rate adjusted for inflation as measured by the GDP deflator' (World Bank, 2013). Annual percentage growth rate of GDP and the percentage of real interest rate are included from 1991-2008 to trace the influence of macroeconomic conditions on welfare of workers.

\section{Statistical method}

To address the above questions in a multivariate setting, this paper provides results from conditional logit regression techniques. Analysing the determinants of job satisfaction, the aim of this paper is to recognise factors responsible for the gradual narrowing in job utility gap between men and women. It is important to recognise that in the economics of welfare, unobserved individual heterogeneity is likely to influence the utility of workers. For example, personality traits, such as being highly motivated or more intelligent are likely to make a worker report higher job satisfaction relative to other workers. Thus, it is important to control for fixed individual effects in order to overcome the problem of possibly having biased coefficients. To do this, conditional fixed effects logit regression technique is used and this estimation methodology eliminates the influence of all fixed individual factors. However, this regression approach does not work well if individual variations are small over time. This means that insufficient variations within individual (and not between individuals) as well as non-identification of time invariant variables, resulting in relatively smaller samples; generate large standard errors (Cameron and Trivedi, 2005). Hence, there is a tradeoff when it comes to choosing one of the two models.

The next section provides the results from both logit regressions and fixed effect logit regressions. While some of the effects of the explanatory variables in logit regressions are in line with the fixed effect estimates, there are a few differences and these are highlighted in the next section. The results also show that fixed effects are playing an important role in explaining the gender gap in job satisfaction. In other words, personality traits and important time-invariant individual factors seem to influence the trends in job utility and are not picked up in the fixed effect logit regressions. Thus, this paper relies on the estimates from logit regression approach and the results from fixed effect logit regressions are provided only for completeness. 


\subsection{Empirical results}

To understand the trends in job utility of British workers, a starting point is to first analyse the effect of variables on satisfaction and subsequently recognise the key factors accountable for the gender gap in job utility. The following equation is estimated:

$J S_{i t}=\alpha_{i}+\beta(E)_{i t}+\gamma^{\prime} X_{i t}+\lambda_{t}+\tau_{t}+e_{i t}$

JSit is overall high satisfaction with current job reported by individual $i$ at time $t, E$ is the educational qualification. The vector $X$ is the set of individual and employment-related characteristics; $\lambda_{t}$ represents aggregate macroeconomic variables and $\tau_{t}$ represents time dummies. The random error term is $e_{i t}$

Although this paper does not aim at exploring determinants of wellbeing, briefly analysing the effect of variables is interesting because of the rich dataset incorporating 18 waves and more importantly, the duration spanning 1991-2008. This is because during this period, Britain witnessed a series of events, such as the recession in the early 1990s and a period of economic boom from 1997-2007. Furthermore, the role of the British government is vital in a societies' wellbeing analysis. The Labour Party came into power in 1997 and a number of regulations and policies were introduced. For example, the National Minimum Wage was introduced in 1999, giving the right to workers not to be paid less than the basic hourly rate. The New Deal Programme for individual aged 18 to 24 became active in 1998 as a part of welfare-to-work strategy, with the twin aim of reducing unemployment and raising employability prospects by providing education or training among those out of work. In 2002, this programme was extended to lone parents, unemployed individuals, disabled and elderly people. Thus, effective regulations and government initiatives on wages, working hours and employment are likely to have an impact on worker's job satisfaction.

Table 3 shows the parameter estimates for high job satisfaction using logit regression approach, controlling for individual and employment-related characteristics as well as aggregate macroeconomic variables. There are 2 specifications, each for men and women. Specification 1 estimates the effect of education and controls for employmentrelated characteristics of the workers as well as time-invariant variables while specification 2 adds the individual characteristics and macroeconomic variables. Establishing the non-monetary benefits of human capital investment, it is of special interest to see the estimated coefficient of education on wellbeing. Consistent with 
previous studies, education is strongly correlated with job satisfaction. Using schooling qualification as the base category, the results confirm that investments in postsecondary schooling results in lower job satisfaction. For men, attaining a postgraduate degree tends to have no effect whereas women are likely to experience lower job utility. University first degree has a negative effect on job satisfaction of men and women, illustrating that workers with undergraduate qualifications are likely to report lower satisfaction levels from their job. Notice that the magnitude of the coefficients is smaller for male workers, suggesting that the negative association between utility and university degree is stronger for women than for men. Furthermore, having a vocational qualification negatively matters for women but their counterparts remain unaffected. Men have higher job satisfaction if they do not hold any educational qualifications whereas the effect for women is statistically insignificant.

\begin{tabular}{|c|c|c|c|c|}
\hline $\begin{array}{l}\text { Table 3: Estimated } \\
\text { parameters from } \\
\text { logit regression }\end{array}$ & & & & \\
\hline High job satisfaction & Men (1) & Men (2) & Women (1) & Women (2) \\
\hline MSc/Phds & $\begin{array}{l}0.034 \\
(0.117)\end{array}$ & $\begin{array}{l}0.085 \\
(0.118)\end{array}$ & $\begin{array}{l}-0.373^{\star \star \star} \\
(0.133)\end{array}$ & $\begin{array}{l}-0.354^{\star \star \star} \\
(0.132)\end{array}$ \\
\hline University first degree & $\begin{array}{l}-0.182^{\star \star \star} \\
(0.066)\end{array}$ & $\begin{array}{l}-0.141^{* *} \\
(0.066)\end{array}$ & $\begin{array}{l}-0.316^{\star \star \star} \\
(0.061)\end{array}$ & $\begin{array}{l}-0.287^{\star \star \star} \\
(0.062)\end{array}$ \\
\hline Vocational & $\begin{array}{l}-0.090 \\
(0.077)\end{array}$ & $\begin{array}{l}-0.067 \\
(0.077)\end{array}$ & $\begin{array}{l}-0.184^{* *} \\
(0.075)\end{array}$ & $\begin{array}{l}-0.152^{* *} \\
(0.076)\end{array}$ \\
\hline No qualification & $\begin{array}{l}0.161^{* \star} \\
(0.063)\end{array}$ & $\begin{array}{l}0.157^{\star *} \\
(0.063)\end{array}$ & $\begin{array}{l}0.001 \\
(0.066)\end{array}$ & $\begin{array}{l}0.009 \\
(0.066)\end{array}$ \\
\hline Unemployment spell & $\begin{array}{l}-0.194^{\star \star \star} \\
(0.051)\end{array}$ & $\begin{array}{l}-0.198^{\star \star \star} \\
(0.052)\end{array}$ & $\begin{array}{l}-0.219^{\star \star \star} \\
(0.063)\end{array}$ & $\begin{array}{l}-0.187^{\star \star \star} \\
(0.063)\end{array}$ \\
\hline Year of birth & $\begin{array}{l}-0.001 \\
(0.002)\end{array}$ & $\begin{array}{l}-0.008 \\
(0.043)\end{array}$ & $\begin{array}{l}-0.005^{\star \star} \\
(0.002)\end{array}$ & $\begin{array}{l}-0.023 \\
(0.041)\end{array}$ \\
\hline Year of birth squared & $\begin{array}{l}-0.183^{*} \\
(0.097)\end{array}$ & $\begin{array}{l}-0.017 \\
(0.108)\end{array}$ & $\begin{array}{l}-0.332^{\star \star \star} \\
(0.110)\end{array}$ & $\begin{array}{l}-0.290^{\star *} \\
(0.116)\end{array}$ \\
\hline UK born & $\begin{array}{l}0.392^{* * *} \\
(0.137)\end{array}$ & $\begin{array}{l}0.420^{\star \star \star} \\
(0.138)\end{array}$ & $\begin{array}{l}0.022 \\
(0.142)\end{array}$ & $\begin{array}{l}-0.019 \\
(0.142)\end{array}$ \\
\hline Small firm & $\begin{array}{l}0.246^{\star \star *} \\
(0.037)\end{array}$ & $\begin{array}{l}0.247^{\star \star *} \\
(0.038)\end{array}$ & $\begin{array}{l}0.267^{\star \star \star} \\
(0.038)\end{array}$ & $\begin{array}{l}0.261^{\star \star *} \\
(0.038)\end{array}$ \\
\hline Working hours & $\begin{array}{l}-0.255^{\star \star \star} \\
(0.069)\end{array}$ & $\begin{array}{l}-0.230^{\star * *} \\
(0.073)\end{array}$ & $\begin{array}{l}-0.341^{* * \star} \\
(0.042)\end{array}$ & $\begin{array}{l}-0.264^{\star \star \star} \\
(0.045)\end{array}$ \\
\hline Manager & $\begin{array}{l}0.575^{\star \star *} \\
(0.082)\end{array}$ & $\begin{array}{l}0.580^{\star \star *} \\
(0.083)\end{array}$ & $\begin{array}{l}0.327^{\star \star \star} \\
(0.088)\end{array}$ & $\begin{array}{l}0.324^{* * *} \\
(0.089)\end{array}$ \\
\hline Professional & $\begin{array}{l}0.500^{* * *} \\
(0.098)\end{array}$ & $\begin{array}{l}0.496^{* * *} \\
(0.099)\end{array}$ & $\begin{array}{l}0.205^{\star *} \\
(0.098)\end{array}$ & $\begin{array}{l}0.189^{*} \\
(0.099)\end{array}$ \\
\hline Technical & $\begin{array}{l}0.507^{\star \star \star} \\
(0.089)\end{array}$ & $\begin{array}{l}0.546^{\star \star \star} \\
(0.089)\end{array}$ & $\begin{array}{l}0.306^{\star \star \star} \\
(0.090)\end{array}$ & $\begin{array}{l}0.329^{\star \star \star} \\
(0.091)\end{array}$ \\
\hline
\end{tabular}




\begin{tabular}{|c|c|c|c|c|}
\hline Clerical & $\begin{array}{l}-0.131 \\
(0.083)\end{array}$ & $\begin{array}{l}-0.113 \\
(0.084)\end{array}$ & $\begin{array}{l}0.119 \\
(0.077)\end{array}$ & $\begin{array}{l}0.119 \\
(0.077)\end{array}$ \\
\hline Craft & $\begin{array}{l}0.331^{* \star \star} \\
(0.079)\end{array}$ & $\begin{array}{l}0.323^{\star \star \star} \\
(0.079)\end{array}$ & $\begin{array}{l}0.191 \\
(0.122)\end{array}$ & $\begin{array}{l}0.190 \\
(0.122)\end{array}$ \\
\hline Personal & $\begin{array}{l}0.225^{\star \star} \\
(0.098)\end{array}$ & $\begin{array}{l}0.232^{\star *} \\
(0.098)\end{array}$ & $\begin{array}{l}0.354^{\star \star \star} \\
(0.079)\end{array}$ & $\begin{array}{l}0.366^{* \star *} \\
(0.079)\end{array}$ \\
\hline Sales & $\begin{array}{l}0.145 \\
(0.094)\end{array}$ & $\begin{array}{l}0.142 \\
(0.094)\end{array}$ & $\begin{array}{l}-0.037 \\
(0.083)\end{array}$ & $\begin{array}{l}-0.020 \\
(0.084)\end{array}$ \\
\hline Plant and machinery & $\begin{array}{l}0.042 \\
(0.078)\end{array}$ & $\begin{array}{l}0.029 \\
(0.078)\end{array}$ & $\begin{array}{l}-0.154 \\
(0.105)\end{array}$ & $\begin{array}{l}-0.172 \\
(0.105)\end{array}$ \\
\hline Promotion & $\begin{array}{l}0.646^{\star \star \star} \\
(0.035)\end{array}$ & $\begin{array}{l}0.649^{\star \star \star} \\
(0.035)\end{array}$ & $\begin{array}{l}0.511^{\star * \star} \\
(0.035)\end{array}$ & $\begin{array}{l}0.510^{\star \star \star *} \\
(0.035)\end{array}$ \\
\hline Job tenure & $\begin{array}{l}-0.011^{\star * \star} \\
(0.003)\end{array}$ & $\begin{array}{l}-0.011^{\star \star \star} \\
(0.003)\end{array}$ & $\begin{array}{l}-0.013^{\star \star \star} \\
(0.004)\end{array}$ & $\begin{array}{l}-0.014^{\star \star \star} \\
(0.004)\end{array}$ \\
\hline Second job & $\begin{array}{l}-0.074 \\
(0.059)\end{array}$ & $\begin{array}{l}-0.079 \\
(0.059)\end{array}$ & $\begin{array}{l}-0.053 \\
(0.053)\end{array}$ & $\begin{array}{l}-0.035 \\
(0.054)\end{array}$ \\
\hline Civil service & $\begin{array}{l}-0.111 \\
(0.098)\end{array}$ & $\begin{array}{l}-0.101 \\
(0.097)\end{array}$ & $\begin{array}{l}-0.183^{*} \\
(0.101)\end{array}$ & $\begin{array}{l}-0.151 \\
(0.101)\end{array}$ \\
\hline Local government & $\begin{array}{l}0.181^{* *} \\
(0.078)\end{array}$ & $\begin{array}{l}0.206^{* * *} \\
(0.078)\end{array}$ & $\begin{array}{l}0.204^{* * *} \\
(0.059)\end{array}$ & $\begin{array}{l}0.208^{\star \star \star} \\
(0.059)\end{array}$ \\
\hline Other public & $\begin{array}{l}0.177^{*} \\
(0.098)\end{array}$ & $\begin{array}{l}0.198^{* *} \\
(0.096)\end{array}$ & $\begin{array}{l}0.270^{* * *} \\
(0.070)\end{array}$ & $\begin{array}{l}0.277^{\star \star \star} \\
(0.070)\end{array}$ \\
\hline Non profit & $\begin{array}{l}0.395^{\star \star} \\
(0.166)\end{array}$ & $\begin{array}{l}0.461^{\star \star \star} \\
(0.163)\end{array}$ & $\begin{array}{l}0.213^{\star *} \\
(0.086)\end{array}$ & $\begin{array}{l}0.243^{\star \star \star} \\
(0.086)\end{array}$ \\
\hline 1991 & $\begin{array}{l}-0.383^{\star \star \star} \\
(0.069)\end{array}$ & $\begin{array}{l}-1.269 \\
(1.505)\end{array}$ & $\begin{array}{l}-0.273^{\star \star \star} \\
(0.074)\end{array}$ & $\begin{array}{l}-1.350 \\
(1.438)\end{array}$ \\
\hline 1992 & $\begin{array}{l}-0.200^{*} \\
(0.105)\end{array}$ & $\begin{array}{l}-1.161 \\
(1.485)\end{array}$ & $\begin{array}{l}0.241^{*} \\
(0.124)\end{array}$ & $\begin{array}{l}-0.857 \\
(1.418)\end{array}$ \\
\hline 1993 & $\begin{array}{l}-0.289^{\star * \star} \\
(0.100)\end{array}$ & $\begin{array}{l}-0.627 \\
(0.699)\end{array}$ & $\begin{array}{l}0.173 \\
(0.119)\end{array}$ & $\begin{array}{l}-0.286 \\
(0.668)\end{array}$ \\
\hline 1994 & $\begin{array}{l}-0.055 \\
(0.101)\end{array}$ & $\begin{array}{l}-0.419 \\
(0.638)\end{array}$ & $\begin{array}{l}-0.120 \\
(0.108)\end{array}$ & $\begin{array}{l}-0.575 \\
(0.614)\end{array}$ \\
\hline 1995 & $\begin{array}{l}-0.138^{* *} \\
(0.067)\end{array}$ & $\begin{array}{l}-0.584 \\
(0.733)\end{array}$ & $\begin{array}{l}-0.007 \\
(0.074)\end{array}$ & $\begin{array}{l}-0.536 \\
(0.700)\end{array}$ \\
\hline 1996 & $\begin{array}{l}-0.101 \\
(0.067)\end{array}$ & $\begin{array}{l}-0.217 \\
(0.350)\end{array}$ & $\begin{array}{l}0.016 \\
(0.075)\end{array}$ & $\begin{array}{l}-0.186 \\
(0.334)\end{array}$ \\
\hline 1997 & $\begin{array}{l}0.106 \\
(0.065)\end{array}$ & $\begin{array}{l}-0.124 \\
(0.422)\end{array}$ & $\begin{array}{l}0.042 \\
(0.070)\end{array}$ & $\begin{array}{l}-0.248 \\
(0.404)\end{array}$ \\
\hline 1998 & $\begin{array}{l}-0.117^{*} \\
(0.062)\end{array}$ & $\begin{array}{l}-0.759 \\
(0.827)\end{array}$ & $\begin{array}{l}0.033 \\
(0.069)\end{array}$ & $\begin{array}{l}-0.628 \\
(0.792)\end{array}$ \\
\hline 1999 & $\begin{array}{l}-0.125^{\star *} \\
(0.057)\end{array}$ & $\begin{array}{l}-0.416 \\
(0.392)\end{array}$ & $\begin{array}{l}-0.122^{* *} \\
(0.062)\end{array}$ & $\begin{array}{l}-0.424 \\
(0.376)\end{array}$ \\
\hline 2000 & $\begin{array}{l}0.006 \\
(0.055)\end{array}$ & $\begin{array}{l}-0.635 \\
(0.726)\end{array}$ & $\begin{array}{l}-0.017 \\
(0.061)\end{array}$ & $\begin{array}{l}-0.626 \\
(0.698)\end{array}$ \\
\hline 2001 & $\begin{array}{l}-0.008 \\
(0.053)\end{array}$ & $\begin{array}{l}-0.338 \\
(0.373)\end{array}$ & $\begin{array}{l}0.188^{* \star *} \\
(0.060)\end{array}$ & $\begin{array}{l}-0.128 \\
(0.361)\end{array}$ \\
\hline 2003 & $\begin{array}{l}-0.068 \\
(0.054)\end{array}$ & $\begin{array}{l}0.117 \\
(0.296)\end{array}$ & $\begin{array}{l}0.051 \\
(0.058)\end{array}$ & $\begin{array}{l}0.253 \\
(0.286)\end{array}$ \\
\hline 2004 & 0.039 & 0.037 & 0.062 & 0.096 \\
\hline
\end{tabular}




\begin{tabular}{|c|c|c|c|c|}
\hline & $(0.057)$ & $(0.126)$ & $(0.064)$ & $(0.126)$ \\
\hline 2005 & $\begin{array}{l}0.116^{*} \\
(0.060)\end{array}$ & $\begin{array}{l}0.023 \\
(0.080)\end{array}$ & $\begin{array}{l}0.116^{*} \\
(0.067)\end{array}$ & $\begin{array}{l}0.087 \\
(0.083)\end{array}$ \\
\hline 2006 & $\begin{array}{l}0.052 \\
(0.061)\end{array}$ & $\begin{array}{l}0.060 \\
(0.202)\end{array}$ & $\begin{array}{l}0.080 \\
(0.068)\end{array}$ & $\begin{array}{l}0.158 \\
(0.197)\end{array}$ \\
\hline 2007 & $\begin{array}{l}0.237^{\star \star \star} \\
(0.064)\end{array}$ & & $\begin{array}{l}0.142^{\star *} \\
(0.069)\end{array}$ & \\
\hline 2008 & $\begin{array}{l}0.151^{\star \star} \\
(0.066)\end{array}$ & & $\begin{array}{l}0.104 \\
(0.070)\end{array}$ & \\
\hline No health problems & & $\begin{array}{l}0.283^{* \star \star} \\
(0.034)\end{array}$ & & $\begin{array}{l}0.342^{\star * \star} \\
(0.034)\end{array}$ \\
\hline Age & & $\begin{array}{l}-0.075^{\star} \\
(0.045)\end{array}$ & & $\begin{array}{l}-0.064 \\
(0.043)\end{array}$ \\
\hline Age-squared & & $\begin{array}{l}0.001^{* * *} \\
(0.000)\end{array}$ & & $\begin{array}{l}0.001^{* * *} \\
(0.000)\end{array}$ \\
\hline Separated & & $\begin{array}{l}0.045 \\
(0.086)\end{array}$ & & $\begin{array}{l}-0.244^{\star \star *} \\
(0.062)\end{array}$ \\
\hline Single & & $\begin{array}{l}-0.117^{* *} \\
(0.054)\end{array}$ & & $\begin{array}{l}-0.240^{\star * \star} \\
(0.055)\end{array}$ \\
\hline Children & & $\begin{array}{l}0.051^{* *} \\
(0.021)\end{array}$ & & $\begin{array}{l}0.089^{* * *} \\
(0.024)\end{array}$ \\
\hline South & & $\begin{array}{l}0.087 \\
(0.084)\end{array}$ & & $\begin{array}{l}0.234^{* * *} \\
(0.082)\end{array}$ \\
\hline Centre & & $\begin{array}{l}0.185^{\star \star} \\
(0.088)\end{array}$ & & $\begin{array}{l}0.256^{\star \star *} \\
(0.088)\end{array}$ \\
\hline NorthWest & & $\begin{array}{l}0.134 \\
(0.101)\end{array}$ & & $\begin{array}{l}0.027 \\
(0.100)\end{array}$ \\
\hline NorthEast & & $\begin{array}{l}0.091 \\
(0.093)\end{array}$ & & $\begin{array}{l}0.226^{* \star} \\
(0.095)\end{array}$ \\
\hline Wales & & $\begin{array}{l}0.275^{\star \star \star} \\
(0.095)\end{array}$ & & $\begin{array}{l}0.129 \\
(0.088)\end{array}$ \\
\hline Scotland/N.Ireland & & $\begin{array}{l}0.044 \\
(0.087)\end{array}$ & & $\begin{array}{l}0.111 \\
(0.083)\end{array}$ \\
\hline Income & & $\begin{array}{l}0.272 \\
(0.247)\end{array}$ & & $\begin{array}{l}0.009 \\
(0.124)\end{array}$ \\
\hline GDP & & $\begin{array}{l}-0.058 \\
(0.093)\end{array}$ & & $\begin{array}{l}-0.068 \\
(0.089)\end{array}$ \\
\hline Interest Rate & & $\begin{array}{l}0.204 \\
(0.224)\end{array}$ & & $\begin{array}{l}0.195 \\
(0.216)\end{array}$ \\
\hline Constant & $\begin{array}{l}0.733^{* * *} \\
(0.228)\end{array}$ & $\begin{array}{l}1.559 \\
(4.273)\end{array}$ & $\begin{array}{l}2.022^{\star \star \star} \\
(0.230)\end{array}$ & $\begin{array}{l}4.088 \\
(4.054)\end{array}$ \\
\hline Observations & 41983 & 41585 & 45957 & 45616 \\
\hline
\end{tabular}

Source: Own calculations based on the BHPS

Note: Standard errors in parenthesis. Significance is denoted by: ${ }^{* *} p<0.01,{ }^{* *} p<0.05,{ }^{*} p<0.1$. 
Thus, workers with high educational achievements report lower satisfaction scores, although they may have better paid jobs and promotional opportunities. This can be explained by raised expectations of workers from their jobs after investing in human capital (Clark, 1996). Furthermore, although more women are attaining university degrees in recent years, the average percentage of women holding a post-secondary qualification in Britain is lower than that of men (see descriptive statistics); consequently the average wellbeing of women is higher. Also, looking at the educational trends (see Figure 2), both men and women are steadily increasing in attaining post-secondary qualifications over the years and given the negative correlation between education and job satisfaction, increasing investments in human capital are unlikely to explain the enhanced welfare of British workers.

Past unemployment spells have a negative effect on current job utility. From specification 2, it is statistically significant at $1 \%$ for both men and women. Similar to Clark et al. (2001) whose study analysed the psychological and scarring impact of unemployment on life satisfaction; this analysis evaluates the effect of past unemployment spells on current job satisfaction. Both men and women dislike losing their jobs and the event of a job loss in the previous period continues to influence work utility, even when workers are back in employment. Ceteris paribus, men derive lower satisfaction levels from their current jobs than female workers, after having experienced unemployment in the past. It is important to recognise that unemployment may be voluntary in some cases, where workers may prefer to claim benefits rather than a low wage. On the other hand, workers may be forced to leave employment, which is beyond their choice. Voluntary or involuntary, past unemployment experiences depress satisfaction levels with the present job. Aggregate unemployment rates also cannot be ignored as a rise in national joblessness sends a negative signal to both employed and unemployed individuals, triggering job insecurity and reduced chances of finding a job, respectively. And unemployment rates are heavily influenced by business cycles. Thus, to track the effect of business cycles on workers utility, annual GDP growth and real interest rate are employed to study the macroeconomics of wellbeing. However, the results show that GDP growth and real interest rates are insignificant at conventional levels.

After controlling for all background characteristics in specification 2, year of birth is not significant at conventional levels. Job utility is associated positively with those born in Britain but matters only for men. Workers in small establishments are likely to have a higher job satisfaction and working 30 hours or more per week is associated negatively with job satisfaction. Also, those higher on the occupational scale, such as managers, professionals as well as those in technical professions and workers with personal occupation are more satisfied with their current job. Workers in sales and clerical occupations show no effect. Men in craft are happier but women show no effect. The availability of promotion opportunities is positively correlated with job satisfaction while job tenure has a negative effect for both men and women. Workers having a second job appear to have no effect on the current job satisfaction. Using 
private firm as the base category, workers in local government, other public services and non-profit organisations are likely to report higher levels of job satisfaction.

Analysing the impact of individual characteristics on job satisfaction, workers with no health problems tend to be more satisfied. The results also show that age has a negative effect but only for men while age squared is positively significant at $1 \%$. Furthermore, separated and single workers are likely to be more dissatisfied than married workers. The number of children in the household is positively correlated with the wellbeing of employed men and women. Using London as a base category, a few geographic locations show a positive association with the dependent variable. Monthly income exhibits a positive magnitude but is statistically insignificant.

Thus, among all the determinants of job satisfaction, what factors can explain the gradual increase in job utility of British workers, especially enhanced welfare of men over the years? To answer this, trends in the raw data of all covariates were analysed and interestingly, one determinant of job utility that can explain the gender gap is past unemployment spells. Figure 3 plots the trends in past unemployment spells experienced by workers over the survey period, by gender. A worker may have lost his/her job multiple times in the past 12 months but the graphical representation shows total spells in unemployment experienced by a worker in the last year. A steady downward trend can be observed for both men and women, suggesting a gradual decline over the years in the proportion of workers out of work. This indicates that male unemployment was almost twice as frequent as female unemployment in the early 1990s. The recession during this period is responsible for job reductions in Britain and was more concentrated among male workers, contributing $81 \%$ of job losses in the early 1990s (Bell and Blanchflower, 2010). A considerable decline in unemployment spells over the years can be seen and the percentage drop is much higher for men than women. It can be observed from the figure that job losses dropped to $7.62 \%$ for male workers and $4.97 \%$ for female workers, thus narrowing the gender gap in the proportion of workers that experienced unemployment. 
Figure 3. Unemployment spells-year to September 1

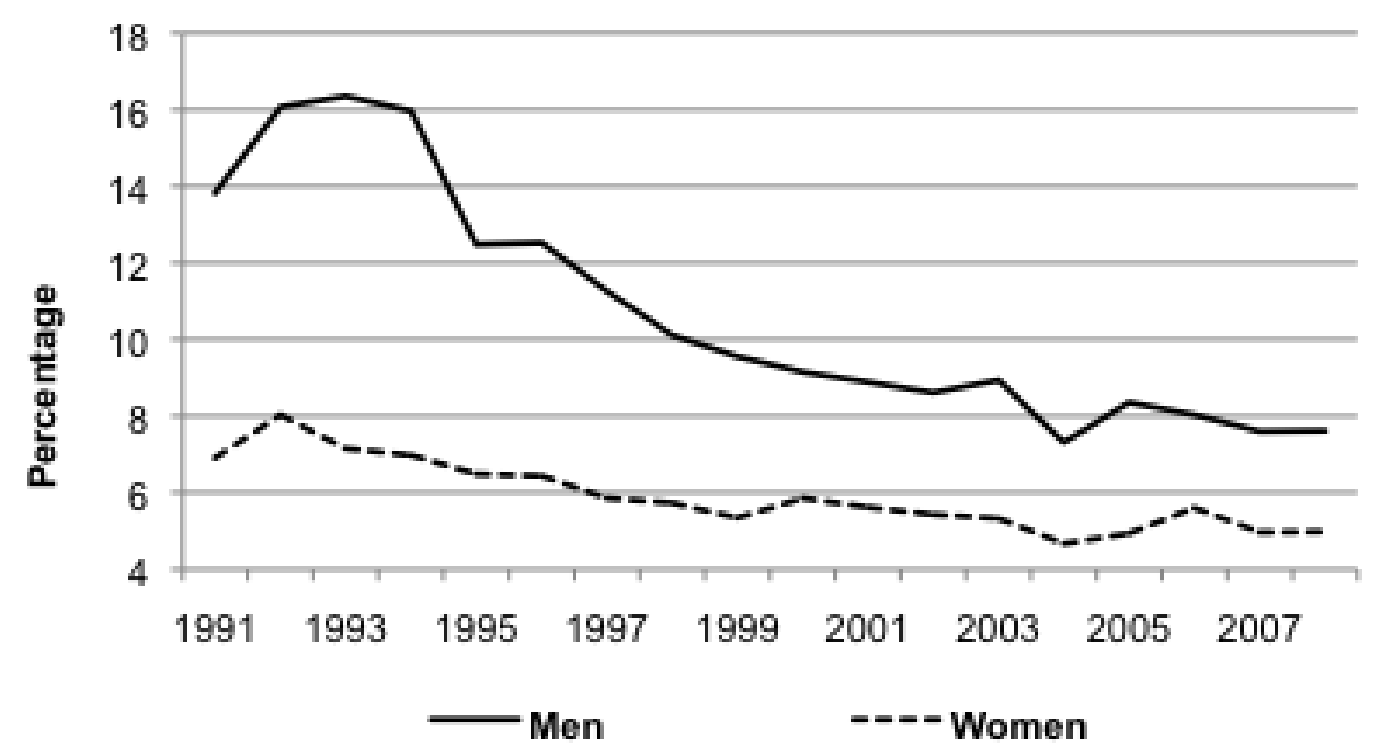

Source: Own calculation based on the BHPS

Overall, workers dislike experiencing a job loss because it is associated with loss in income and it influences non-monetary aspects, such as social status as well as social connections and overall wellbeing (Clark et al., 2010). Workers that experienced past unemployment spells report lower current job satisfaction, illustrating a scarring effect on utility from work. And from Figure 3, the unemployment differential between men and women is noticeably large in the 1990s and gradually shrinking with time. Ceteris paribus, the steady decline in the proportion of workers losing their jobs in previous years and its corresponding negative correlation with current job utility contributes to answering the question as to why men report higher scores in job utility in recent years and are catching up to women's satisfaction levels. Declining rates of unemployment has resulted in enhancing welfare, for both men and women. There is evidence that men are more dissatisfied relative to women after experiencing unemployment. Thus, with fewer men experiencing unemployment in recent years and its corresponding negative correlation with wellbeing is likely to explain increasing welfare among male workers. It is out of the scope of this paper to understand the factors contributing to the decline in unemployment over the years. One possible explanation is the economic climate of Britain. According to the World Bank data, aggregate variables, such as total unemployment recorded for Britain in 1991 was $8.4 \%$ and it increased to $10.3 \%$ in $1993 .{ }^{3} \mathrm{~A}$ gradual decline in these figures started from 1994 and recorded to $4.6 \%$ by 2005. By 2008, total unemployment in Britain recorded was $5.3 \%$.

\footnotetext{
3 According to the World Bank, development indicators such as unemployment rate are defined as 'the share of the labour force that is without work but available and seeking employment' (The World Bank, 2013).
} 
Table 3.1 reports the marginal effects separately for both men and women using specification 2. As shown, past unemployment spells has a negative effect on current job satisfaction. The marginal effects reported are -0.034 and -0.025 for men and women respectively. Analysing educational attainment, attaining a university first degree has a negative impact on job satisfaction. As shown in the table, the marginal effects are -0.024 for men and -0.039 for women. The marginal effects of the remaining variables are also provided below.

\begin{tabular}{|l|r|r|r|r|r|r|}
\hline $\begin{array}{l}\text { Table 3.1: Marginal } \\
\text { effects calculated } \\
\text { at the mean }\end{array}$ & & & & & & \\
\hline High job satisfaction & dy/dx & Std Dev & P $>|\mathrm{z}|$ & $\mathrm{dy} / \mathrm{dx}$ & Std Dev & $\mathrm{P}>|\mathrm{z}|$ \\
\hline & Men & Men & Men & Women & Women & Women \\
\hline (Predict) & 0.791 & & & 0.850 & & \\
\hline MSc/Phds & 0.014 & 0.019 & 0.459 & -0.051 & 0.021 & 0.016 \\
\hline $\begin{array}{l}\text { University first } \\
\text { degree }\end{array}$ & -0.024 & 0.011 & 0.036 & -0.039 & 0.009 & 0.000 \\
\hline Vocational & -0.011 & 0.013 & 0.393 & -0.020 & 0.011 & 0.054 \\
\hline No qualification & 0.025 & 0.010 & 0.010 & 0.001 & 0.008 & 0.896 \\
\hline Unemployment spell & -0.034 & 0.009 & 0.000 & -0.025 & 0.009 & 0.005 \\
\hline Year of birth & -0.001 & 0.007 & 0.863 & -0.003 & 0.005 & 0.573 \\
\hline Year of birth \\
squared & -0.00 & 0.018 & 0.874 & -0.034 & 0.012 & 0.006 \\
\hline UK born & -0.019 & 0.015 & 0.186 & 0.015 & 0.009 & 0.115 \\
\hline Small firm & 0.078 & 0.028 & 0.006 & -0.002 & 0.018 & 0.894 \\
\hline Working hours & -0.036 & 0.011 & 0.001 & -0.033 & 0.005 & 0.000 \\
\hline Manager & 0.086 & 0.011 & 0.000 & 0.038 & 0.010 & 0.000 \\
\hline Professional & 0.073 & 0.013 & 0.000 & 0.023 & 0.011 & 0.043 \\
\hline Technical & 0.079 & 0.011 & 0.000 & 0.039 & 0.010 & 0.000 \\
\hline Clerical & 0.006 & 0.000 & 0.033 & 0.005 & 0.000 \\
\hline Craft & 0.012 & 0.000 & 0.023 & 0.014 & 0.097 \\
\hline
\end{tabular}




\begin{tabular}{|l|r|r|r|r|r|r|}
\hline & & & & & \\
\hline Personal & 0.036 & 0.014 & 0.012 & 0.043 & 0.009 & 0.000 \\
\hline Sales & 0.023 & 0.014 & 0.116 & -0.003 & 0.011 & 0.812 \\
\hline Plant and machinery & 0.005 & 0.013 & 0.709 & -0.023 & 0.015 & 0.120 \\
\hline No health problems & 0.047 & 0.006 & 0.000 & 0.043 & 0.004 & 0.000 \\
\hline Promotion & 0.109 & 0.006 & 0.000 & 0.065 & 0.004 & 0.000 \\
\hline Job tenure & -0.002 & 0.001 & 0.002 & -0.002 & 0.001 & 0.001 \\
\hline Second job & -0.013 & 0.010 & 0.191 & -0.005 & 0.007 & 0.517 \\
\hline Civil service & -0.017 & 0.017 & 0.310 & -0.020 & 0.014 & 0.153 \\
\hline Local government & 0.032 & 0.012 & 0.005 & 0.025 & 0.007 & 0.000 \\
\hline Other public & 0.031 & 0.014 & 0.029 & 0.033 & 0.008 & 0.000 \\
\hline Non profit & 0.067 & 0.020 & 0.001 & 0.029 & 0.009 & 0.002 \\
\hline Age & -0.010 & 0.015 & 0.534 & -0.009 & 0.011 & 0.445 \\
\hline Age Squared & 0.012 & 0.007 & 0.096 & -0.008 & 0.006 & 0.143 \\
\hline Separated & 0.000 & 0.000 & 0.000 & 0.000 & 0.000 & 0.001 \\
\hline Single & 0.007 & 0.014 & 0.599 & -0.033 & 0.009 & 0.000 \\
\hline Children & -0.020 & 0.009 & 0.035 & -0.032 & 0.008 & 0.000 \\
\hline South & 0.008 & 0.003 & 0.012 & 0.011 & 0.003 & 0.000 \\
\hline Centre & 0.014 & 0.013 & 0.293 & 0.028 & 0.010 & 0.003 \\
\hline NorthWest & 0.014 & 0.030 & 0.031 & 0.010 & 0.002 \\
\hline NorthEast & 0.015 & 0.015 & 0.322 & 0.027 & 0.011 & 0.012 \\
\hline Wales & 0.014 & 0.002 & 0.016 & 0.011 & 0.130 \\
\hline Scotland/N.Ireland & 0.014 & 0.614 & 0.014 & 0.010 & 0.171 \\
\hline & & & & & & \\
\hline
\end{tabular}




\begin{tabular}{|l|l|l|l|l|l|l|}
\hline Interest rate & 0.034 & 0.037 & 0.362 & 0.025 & 0.028 & 0.367 \\
\hline
\end{tabular}

Source: Own calculations based on the BHPS

At this stage, it is interesting to analyse the convergence in unemployment to convergence in job satisfaction. As shown in the results, job satisfaction has increased over the years for male workers, while job satisfaction for women is relatively stable. This has resulted in some convergence as men are gradually catching up to women's higher satisfaction score. It is argued that unemployment has a negative effect on satisfaction and is contributing to this convergence, explaining further that unemployment rates have fallen more for men than women. Below are some back-ofan-envelope calculations on the likely contribution of convergence in unemployment rates to the convergence in satisfaction. For example, multiplying the marginal effect of unemployment on satisfaction by the difference in unemployment incidence, say, between 1992-4 and 2005-8. To do this, first the marginal effect of unemployment on job satisfaction calculated is -0.034 for men and -0.025 for women. Secondly, the unemployment incidence from $1992-94$ is $16.1 \%, 16.4 \%, 16.0 \%$ for men and $8.0 \%$, $7.1 \%, 7.0 \%$ for women. Similarly, the unemployment rates from $2005-08$ was $8.4 \%$, $8.0 \%, 7.6 \%, 7.6 \%$ for male workers while for women, the unemployment incidence was $4.9 \%, 5.6 \%, 5.0 \%$ and $5.0 \%$. Computing the average for 1992-94, the unemployment rate was 16.17 and 7.37 for men and women respectively. Similarly, the average calculated for $2005-08$ is $7.9 \%$ and $5.12 \%$ for men and women respectively. From the above values, the difference in unemployment between 199294 and $2005-08$ is $8.3 \%$ for men and $2.3 \%$ for women. Multiplying the marginal effect $(-0.034$ for men and -0.025 for women) by the difference in unemployment incidence, i.e. $-0.034^{*}-0.083=0.0028$ for men and $-0.025^{*}-0.023=0.0006$. The difference calculated is 0.0022 . The gap in job satisfaction is from 10 percent to $6 \%$ and therefore a convergence of 4 percentage points. Thus, the contribution of the unemployment difference is $0.0022 / 0.04$ or about $6 \%$. And although this contribution of convergence in unemployment rates to convergence in job satisfaction between men and women is small, unemployment is shown to be a factor responsible for the convergence in job satisfaction between men and women.

It is important to point out the issue of reverse causation, i.e. unhappiness is likely to cause unemployment. Furthermore, in the economics of welfare, unobserved individual heterogeneity is likely to influence the utility of workers. Therefore in the next section, fixed effect logit regressions are used to account for unobserved heterogeneity. And, the effect of frequent changes in economic status in three consecutive time periods, i.e. the effect of having no unemployment spells in year t-2 to experiencing job losses in year $\mathrm{t}-1$ and then back to employment in year $\mathrm{t}$ on current job satisfaction is analysed. It is assumed that direction of the effect is 
expected to be calculated more appropriately, i.e. the probability of unemployment on job satisfaction and not the effect of wellbeing on unemployment.

\subsection{Fixed effect logit regressions}

To control for fixed effects such as personality traits, this section discusses the results obtained from conditional fixed effect logit regressions. Table 4 shows that even after controlling for fixed individual effects, the probability of enhanced welfare drops substantially after gaining a university qualification for both men and women. As mentioned earlier, higher educated workers are likely to be in jobs that are well paid and that may come with promotional opportunities. At the same time, education raises expectations in regards to its returns (Clark, 1996). Overall, workers without a postsecondary schooling qualification report higher satisfaction scores. On the other hand, the probability of reporting higher job satisfaction is substantially lower for workers with higher educational achievements, such as a university qualification. It is clear that women are more dissatisfied with their jobs than men after attaining a university degree. This seems to be more in line with higher expectations from their jobs (Clark, 1997). However, it is important to note that on average a higher percentage of women than men have no qualifications in Britain (see descriptive statistics). This low education combined with poorer positions in the job market, reflected by low wages and lack of promotion opportunities, lowers expectations of female workers. Consequently, women report higher job satisfaction than their counterparts. Table 4 also shows that even after controlling for fixed effects, the unfortunate event of a job loss in earlier periods exhibits a negative effect on the current job satisfaction of workers. These estimates provide evidence that unemployment spells lower the probability of reporting high wellbeing for both men and women, but are not significant at conventional levels. Previous studies have documented that unemployed individuals are extremely unhappy (Winkelmann and Winkelmann, 1998). Unemployment also raises the likelihood of loss in self-esteem when workers are out of jobs (Goldsmith et al., 1996). And finally, as mentioned earlier, psychological imprints of unemployment continue to scar individual wellbeing (Clark et al., 2001). It is clear that previous spells in unemployment tend to depress present job satisfaction of workers. Although the contribution of convergence in unemployment rates to convergence in job satisfaction between men and women is small, unemployment is shown to be a factor responsible for the convergence in job satisfaction between men and women. And patterns of declining unemployment trends, especially for men, suggests that fewer men were out of jobs in recent years compared to the early 1990s. This is likely to explain the gradual increase in job satisfaction of male workers. On the other hand, fewer women tend to participate in the labour market and therefore unemployment rates are much smaller relative to their counterparts as well as a smaller percentage drop in unemployment is seen over the years. On average women report higher satisfaction scores. 


\begin{tabular}{|c|c|c|c|c|}
\hline $\begin{array}{l}\text { Table 4: Estimated } \\
\text { parameters from } \\
\text { fixed effect logit } \\
\text { regression }\end{array}$ & & & & \\
\hline High job satisfaction & Men (1) & Men (2) & Women (1) & Women (2) \\
\hline MSc/Phds & $\begin{array}{l}-0.291 \\
(0.289)\end{array}$ & $\begin{array}{l}-0.243 \\
(0.295)\end{array}$ & $\begin{array}{l}0.248 \\
(0.319)\end{array}$ & $\begin{array}{l}0.155 \\
(0.322)\end{array}$ \\
\hline University first degree & $\begin{array}{l}-0.375^{\star *} \\
(0.167)\end{array}$ & $\begin{array}{l}-0.304^{\star} \\
(0.170)\end{array}$ & $\begin{array}{l}-0.409^{\star * *} \\
(0.140)\end{array}$ & $\begin{array}{l}-0.440^{* * *} \\
(0.142)\end{array}$ \\
\hline Vocational & $\begin{array}{l}-0.055 \\
(0.225)\end{array}$ & $\begin{array}{l}0.025 \\
(0.230)\end{array}$ & $\begin{array}{l}-0.411^{*} \\
(0.218)\end{array}$ & $\begin{array}{l}-0.428^{*} \\
(0.220)\end{array}$ \\
\hline No qualification & $\begin{array}{l}0.133 \\
(0.311)\end{array}$ & $\begin{array}{l}0.166 \\
(0.309)\end{array}$ & $\begin{array}{l}0.741^{* * *} \\
(0.286)\end{array}$ & $\begin{array}{l}0.739^{\star * \star} \\
(0.285)\end{array}$ \\
\hline Unemployment spell & $\begin{array}{l}-0.021 \\
(0.068)\end{array}$ & $\begin{array}{l}-0.027 \\
(0.069) \\
\end{array}$ & $\begin{array}{l}-0.048 \\
(0.082)\end{array}$ & $\begin{array}{l}-0.039 \\
(0.082)\end{array}$ \\
\hline Small firm & $\begin{array}{l}0.141^{* \star *} \\
(0.044)\end{array}$ & $\begin{array}{l}0.142^{\star * *} \\
(0.044)\end{array}$ & $\begin{array}{l}0.086^{*} \\
(0.047)\end{array}$ & $\begin{array}{l}0.091^{*} \\
(0.047)\end{array}$ \\
\hline Working hours & $\begin{array}{l}-0.273^{* \star *} \\
(0.094)\end{array}$ & $\begin{array}{l}-0.244^{\star *} \\
(0.096)\end{array}$ & $\begin{array}{l}-0.319^{\star \star *} \\
(0.051)\end{array}$ & $\begin{array}{l}-0.282^{\star \star \star} \\
(0.053)\end{array}$ \\
\hline Manager & $\begin{array}{l}0.464^{\star \star \star} \\
(0.099)\end{array}$ & $\begin{array}{l}0.472^{* \star *} \\
(0.100)\end{array}$ & $\begin{array}{l}0.221^{* *} \\
(0.112)\end{array}$ & $\begin{array}{l}0.210^{*} \\
(0.113)\end{array}$ \\
\hline Professional & $\begin{array}{l}0.475^{* * *} \\
(0.114)\end{array}$ & $\begin{array}{l}0.489^{* * *} \\
(0.115)\end{array}$ & $\begin{array}{l}0.271^{* *} \\
(0.125)\end{array}$ & $\begin{array}{l}0.257^{\star \star} \\
(0.127)\end{array}$ \\
\hline Technical & $\begin{array}{l}0.744^{* *} \\
(0.106)\end{array}$ & $\begin{array}{l}0.763^{\star * *} \\
(0.107)\end{array}$ & $\begin{array}{l}0.458^{\star * *} \\
(0.116)\end{array}$ & $\begin{array}{l}0.457^{* * *} \\
(0.118)\end{array}$ \\
\hline Clerical & $\begin{array}{l}0.138 \\
(0.099)\end{array}$ & $\begin{array}{l}0.152 \\
(0.100)\end{array}$ & $\begin{array}{l}0.157 \\
(0.102)\end{array}$ & $\begin{array}{l}0.152 \\
(0.103)\end{array}$ \\
\hline Craft & $\begin{array}{l}0.497^{* * *} \\
(0.098)\end{array}$ & $\begin{array}{l}0.517^{\star \star \star} \\
(0.098)\end{array}$ & $\begin{array}{l}-0.066 \\
(0.174)\end{array}$ & $\begin{array}{l}-0.089 \\
(0.175)\end{array}$ \\
\hline Personal & $\begin{array}{l}0.190 \\
(0.122)\end{array}$ & $\begin{array}{l}0.184 \\
(0.123)\end{array}$ & $\begin{array}{l}0.266^{* * *} \\
(0.102)\end{array}$ & $\begin{array}{l}0.251^{\star *} \\
(0.102)\end{array}$ \\
\hline Sales & $\begin{array}{l}0.288^{\star \star} \\
(0.116)\end{array}$ & $\begin{array}{l}0.306^{* *} \\
(0.117)\end{array}$ & $\begin{array}{l}-0.028 \\
(0.108)\end{array}$ & $\begin{array}{l}-0.036 \\
(0.109)\end{array}$ \\
\hline Plant and machinery & $\begin{array}{l}0.030 \\
(0.093)\end{array}$ & $\begin{array}{l}0.037 \\
(0.094)\end{array}$ & $\begin{array}{l}-0.424^{\star \star \star} \\
(0.146)\end{array}$ & $\begin{array}{l}-0.439^{\star \star \star} \\
(0.147)\end{array}$ \\
\hline Promotion & $\begin{array}{l}0.819^{\star \star \star} \\
(0.039)\end{array}$ & $\begin{array}{l}0.828^{\star * \star} \\
(0.040)\end{array}$ & $\begin{array}{l}0.627^{* * *} \\
(0.041)\end{array}$ & $\begin{array}{l}0.627^{* * *} \\
(0.041)\end{array}$ \\
\hline Job tenure & $\begin{array}{l}-0.050^{\star \star \star} \\
(0.004)\end{array}$ & $\begin{array}{l}-0.050^{* \star *} \\
(0.004)\end{array}$ & $\begin{array}{l}-0.059^{\star \star *} \\
(0.005)\end{array}$ & $\begin{array}{l}-0.058^{\star \star \star} \\
(0.005)\end{array}$ \\
\hline Second job & $\begin{array}{l}-0.079 \\
(0.072)\end{array}$ & $\begin{array}{l}-0.087 \\
(0.072)\end{array}$ & $\begin{array}{l}-0.109^{*} \\
(0.065)\end{array}$ & $\begin{array}{l}-0.100 \\
(0.066)\end{array}$ \\
\hline Civil service & $\begin{array}{l}0.220^{\star} \\
(0.131)\end{array}$ & $\begin{array}{l}0.205 \\
(0.132)\end{array}$ & $\begin{array}{l}0.241^{*} \\
(0.144)\end{array}$ & $\begin{array}{l}0.250^{*} \\
(0.144)\end{array}$ \\
\hline Local government & $\begin{array}{l}0.690^{\star * *} \\
(0.113)\end{array}$ & $\begin{array}{l}0.693^{* \star *} \\
(0.114)\end{array}$ & $\begin{array}{l}0.425^{\star \star *} \\
(0.084)\end{array}$ & $\begin{array}{l}0.439^{* * *} \\
(0.084)\end{array}$ \\
\hline Other public & $\begin{array}{l}0.523^{\star * *} \\
(0.123)\end{array}$ & $\begin{array}{l}0.511^{* * *} \\
(0.124)\end{array}$ & $\begin{array}{l}0.469^{* \star *} \\
(0.100)\end{array}$ & $\begin{array}{l}0.483^{\star * *} \\
(0.101)\end{array}$ \\
\hline Non profit & $0.690^{\star \star *}$ & $0.681^{* \star \star}$ & $0.596^{\star * \star}$ & $0.591^{* \star \star}$ \\
\hline
\end{tabular}




\begin{tabular}{|c|c|c|c|c|}
\hline & $(0.190)$ & $(0.191)$ & $(0.115)$ & $(0.116)$ \\
\hline 1991 & $\begin{array}{l}-0.493^{\star \star \star} \\
(0.095)\end{array}$ & $\begin{array}{l}-2.246 \\
(2.137)\end{array}$ & $\begin{array}{l}-0.377^{\star \star \star} \\
(0.099)\end{array}$ & $\begin{array}{l}0.964 \\
(2.195)\end{array}$ \\
\hline 1992 & $\begin{array}{l}-0.198 \\
(0.146)\end{array}$ & $\begin{array}{l}-2.032 \\
(2.106) \\
\end{array}$ & $\begin{array}{l}0.367^{\star \star} \\
(0.159)\end{array}$ & $\begin{array}{l}1.658 \\
(2.164) \\
\end{array}$ \\
\hline 1993 & $\begin{array}{l}-0.608^{* \star *} \\
(0.132)\end{array}$ & $\begin{array}{l}-1.207 \\
(0.992)\end{array}$ & $\begin{array}{l}0.169 \\
(0.152)\end{array}$ & $\begin{array}{l}0.852 \\
(1.020)\end{array}$ \\
\hline 1994 & $\begin{array}{l}-0.093 \\
(0.134)\end{array}$ & $\begin{array}{l}-0.738 \\
(0.911)\end{array}$ & $\begin{array}{l}-0.067 \\
(0.142)\end{array}$ & $\begin{array}{l}0.517 \\
(0.935)\end{array}$ \\
\hline 1995 & $\begin{array}{l}-0.135 \\
(0.089)\end{array}$ & $\begin{array}{l}-0.979 \\
(1.042)\end{array}$ & $\begin{array}{l}-0.007 \\
(0.095)\end{array}$ & $\begin{array}{l}0.644 \\
(1.069)\end{array}$ \\
\hline 1996 & $\begin{array}{l}-0.108 \\
(0.087) \\
\end{array}$ & $\begin{array}{l}-0.334 \\
(0.497)\end{array}$ & $\begin{array}{l}0.006 \\
(0.093)\end{array}$ & $\begin{array}{l}0.374 \\
(0.511) \\
\end{array}$ \\
\hline 1997 & $\begin{array}{l}0.177^{\star *} \\
(0.086)\end{array}$ & $\begin{array}{l}-0.263 \\
(0.601)\end{array}$ & $\begin{array}{l}0.057 \\
(0.089)\end{array}$ & $\begin{array}{l}0.454 \\
(0.617)\end{array}$ \\
\hline 1998 & $\begin{array}{l}-0.128 \\
(0.083)\end{array}$ & $\begin{array}{l}-1.336 \\
(1.176)\end{array}$ & $\begin{array}{l}0.031 \\
(0.088)\end{array}$ & $\begin{array}{l}0.693 \\
(1.205)\end{array}$ \\
\hline 1999 & $\begin{array}{l}-0.110 \\
(0.076)\end{array}$ & $\begin{array}{l}-0.622 \\
(0.558)\end{array}$ & $\begin{array}{l}-0.171^{* \star} \\
(0.079)\end{array}$ & $\begin{array}{l}0.158 \\
(0.572)\end{array}$ \\
\hline 2000 & $\begin{array}{l}0.055 \\
(0.075)\end{array}$ & $\begin{array}{l}-1.125 \\
(1.032)\end{array}$ & $\begin{array}{l}-0.046 \\
(0.078)\end{array}$ & $\begin{array}{l}0.485 \\
(1.058)\end{array}$ \\
\hline 2001 & $\begin{array}{l}0.044 \\
(0.075)\end{array}$ & $\begin{array}{l}-0.561 \\
(0.532)\end{array}$ & $\begin{array}{l}0.185^{\star *} \\
(0.079)\end{array}$ & $\begin{array}{l}0.458 \\
(0.546)\end{array}$ \\
\hline 2003 & $\begin{array}{l}-0.069 \\
(0.076)\end{array}$ & $\begin{array}{l}0.316 \\
(0.418)\end{array}$ & $\begin{array}{l}0.013 \\
(0.080)\end{array}$ & $\begin{array}{l}-0.229 \\
(0.430)\end{array}$ \\
\hline 2004 & $\begin{array}{l}0.092 \\
(0.079)\end{array}$ & $\begin{array}{l}0.125 \\
(0.180)\end{array}$ & $\begin{array}{l}0.043 \\
(0.081)\end{array}$ & $\begin{array}{l}-0.094 \\
(0.185)\end{array}$ \\
\hline 2005 & $\begin{array}{l}0.174^{\star *} \\
(0.080)\end{array}$ & $\begin{array}{l}0.048 \\
(0.110)\end{array}$ & $\begin{array}{l}0.075 \\
(0.082)\end{array}$ & $\begin{array}{l}-0.044 \\
(0.113)\end{array}$ \\
\hline 2006 & $\begin{array}{l}0.136^{*} \\
(0.081)\end{array}$ & $\begin{array}{l}0.193 \\
(0.286)\end{array}$ & $\begin{array}{l}0.070 \\
(0.083)\end{array}$ & $\begin{array}{l}-0.154 \\
(0.295)\end{array}$ \\
\hline 2007 & $\begin{array}{l}0.389^{\star \star \star} \\
(0.085)\end{array}$ & & $\begin{array}{l}0.128 \\
(0.085)\end{array}$ & \\
\hline 2008 & $\begin{array}{l}0.295^{\star * \star} \\
(0.086)\end{array}$ & & $\begin{array}{l}0.083 \\
(0.087)\end{array}$ & \\
\hline No health problems & & $\begin{array}{l}0.159^{\star \star \star} \\
(0.044)\end{array}$ & & $\begin{array}{l}0.164^{\star * *} \\
(0.045)\end{array}$ \\
\hline Age & & $\begin{array}{l}-0.035 \\
(0.064)\end{array}$ & & $\begin{array}{l}0.041 \\
(0.066)\end{array}$ \\
\hline Age-squared & & $\begin{array}{l}0.000 \\
(0.000)\end{array}$ & & $\begin{array}{l}0.000 \\
(0.000)\end{array}$ \\
\hline Separated & & $\begin{array}{l}0.156 \\
(0.116)\end{array}$ & & $\begin{array}{l}-0.051 \\
(0.094)\end{array}$ \\
\hline Single & & $\begin{array}{l}0.023 \\
(0.081) \\
\end{array}$ & & $\begin{array}{l}-0.214^{\star * \star} \\
(0.083)\end{array}$ \\
\hline Children & & $\begin{array}{l}0.071^{* *} \\
(0.028)\end{array}$ & & $\begin{array}{l}0.083^{\star *} \\
(0.033)\end{array}$ \\
\hline South & & $0.507^{\star \star \star}$ & & 0.050 \\
\hline
\end{tabular}




\begin{tabular}{|l|l|l|l|l|}
\hline & & $(0.191)$ & & $(0.173)$ \\
\hline Centre & & $0.602^{* *}$ & & -0.150 \\
& $(0.242)$ & & $(0.223)$ \\
\hline NorthWest & & 0.507 & & -0.315 \\
& & $(0.347)$ & & $(0.316)$ \\
\hline NorthEast & & $0.722^{* *}$ & & 0.016 \\
& $(0.292)$ & & $(0.279)$ \\
\hline Wales & & $0.720^{* *}$ & & -0.461 \\
& $(0.365)$ & & $(0.356)$ \\
\hline Scotland/N.Ireland & & 0.612 & & 0.304 \\
& $(0.385)$ & & $(0.375)$ \\
\hline Income & & -0.210 & & 0.121 \\
& $(0.341)$ & & $(0.164)$ \\
\hline GDP & & -0.122 & & 0.078 \\
& & $(0.131)$ & & $(0.134)$ \\
\hline Interest rate & & 0.385 & & -0.155 \\
& & $(0.318)$ & & $(0.326)$ \\
\hline Observations & 25633 & 25332 & 25072 & 24844 \\
& & & \\
\hline
\end{tabular}

Source: Own calculations based on the BHPS

Note: Standard errors in parenthesis. Significance is denoted by: ${ }^{* * *} p<0.01,{ }^{* *} p<0.05,{ }^{*} p<0.1$.

It is important to note that the participation of women in the labour market has increased over the years and as mentioned before, there is a high probability of sample selection among female workers as they have a choice to opt out especially if they are unhappy with their jobs (Clark, 1997). Therefore, if only satisfied women are more likely to participate in the labour force then average happiness should decline as more women join the labour force. However, the fixed effect logit model can be appreciated here as the coefficients avoid any biases arising from such effects and may only be reflected in the year dummies.

In summary, controlling for fixed effects gives additional confidence in the results. The effect of the remaining covariates is similar to the logit regression results.

\subsection{Changes in economic activity on job utility}

This section moves onto understanding the effect of frequent transitions in economic activity on job utility for men and women. In particular, the transitional effect of having no spells in unemployment in period t-2 to experiencing job losses in year t- 1 is estimated on current job satisfaction scores measured in year t. ${ }^{4}$ Table 5 shows the

\footnotetext{
4 Prior to $\mathrm{t}-1$, these workers did not experience unemployment and in $\mathrm{t}-1$, they may have experienced one or multiple job losses.
} 
effect of the transitional variables below, separately for men and women, using logit regression approach. The transition from employment in year t-2 into unemployment in $\mathrm{t}-1$ displays a negative coefficient on current job satisfaction measured at time $t$ for both men and women. This is not surprising given that unemployment is negatively correlated with wellbeing and has a scarring effect. However, the interesting aspect is the larger magnitude of the coefficient for women. It appears that female workers experience greater dissatisfaction compared to men after encountering frequent changes in economic activity, entering unemployment in period t-1 after exiting employment in period t-2. Thus, analysing changes in economic status in consecutive periods, frequent changes in economic activity hurts women more than men.

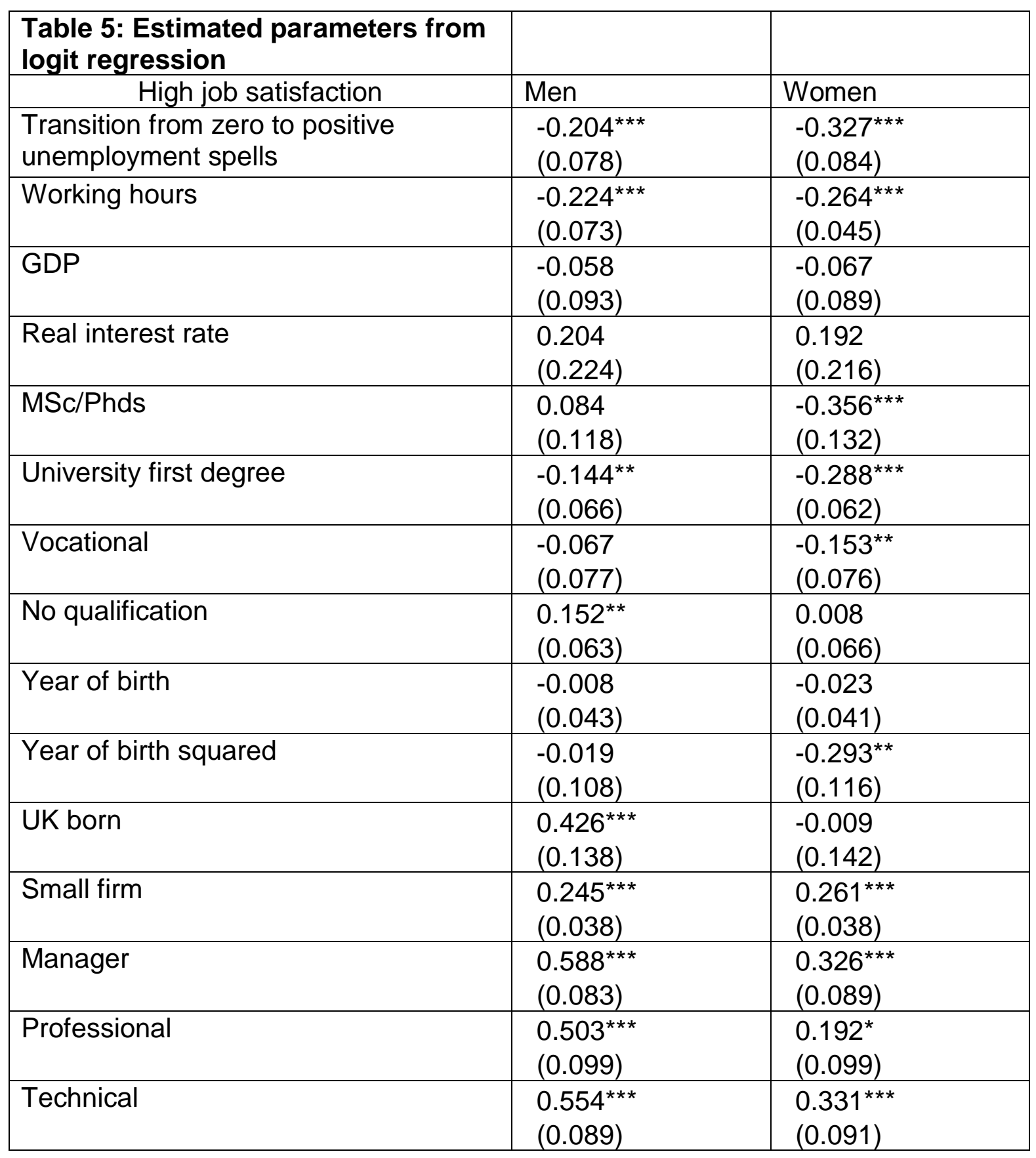




\begin{tabular}{|c|c|c|}
\hline Clerical & $\begin{array}{l}-0.112 \\
(0.084)\end{array}$ & $\begin{array}{l}0.121 \\
(0.077)\end{array}$ \\
\hline Craft & $\begin{array}{l}0.327^{\star \star \star} \\
(0.079)\end{array}$ & $\begin{array}{l}0.190 \\
(0.122)\end{array}$ \\
\hline Personal & $\begin{array}{l}0.235^{\star *} \\
(0.098)\end{array}$ & $\begin{array}{l}0.369^{\star * *} \\
(0.079)\end{array}$ \\
\hline Sales & $\begin{array}{l}0.147 \\
(0.094)\end{array}$ & $\begin{array}{l}-0.019 \\
(0.084)\end{array}$ \\
\hline Plant and machinery & $\begin{array}{l}0.030 \\
(0.078)\end{array}$ & $\begin{array}{l}-0.171 \\
(0.105)\end{array}$ \\
\hline Promotion & $\begin{array}{l}0.651^{* \star *} \\
(0.035)\end{array}$ & $\begin{array}{l}0.511^{* * *} \\
(0.035)\end{array}$ \\
\hline Job tenure & $\begin{array}{l}-0.010^{\star \star \star} \\
(0.003)\end{array}$ & $\begin{array}{l}-0.014^{\star \star \star} \\
(0.004)\end{array}$ \\
\hline Second job & $\begin{array}{l}-0.078 \\
(0.059)\end{array}$ & $\begin{array}{l}-0.034 \\
(0.054)\end{array}$ \\
\hline Civil service & $\begin{array}{l}-0.101 \\
(0.097)\end{array}$ & $\begin{array}{l}-0.153 \\
(0.101)\end{array}$ \\
\hline Local government & $\begin{array}{l}0.205^{\star * *} \\
(0.078)\end{array}$ & $\begin{array}{l}0.208^{* * *} \\
(0.059)\end{array}$ \\
\hline Other public & $\begin{array}{l}0.200^{* *} \\
(0.096)\end{array}$ & $\begin{array}{l}0.277^{* * *} \\
(0.070)\end{array}$ \\
\hline Non profit & $\begin{array}{l}0.460^{\star * \star} \\
(0.164)\end{array}$ & $\begin{array}{l}0.243^{\star * *} \\
(0.086)\end{array}$ \\
\hline No health problems & $\begin{array}{l}0.284^{\star \star \star} \\
(0.034)\end{array}$ & $\begin{array}{l}0.342^{\star \star \star} \\
(0.034)\end{array}$ \\
\hline Age & $\begin{array}{l}-0.073 \\
(0.045)\end{array}$ & $\begin{array}{l}-0.063 \\
(0.043)\end{array}$ \\
\hline Age-squared & $\begin{array}{l}0.001^{* * *} \\
(0.000)\end{array}$ & $\begin{array}{l}0.001^{* * *} \\
(0.000)\end{array}$ \\
\hline Separated & $\begin{array}{l}0.040 \\
(0.086)\end{array}$ & $\begin{array}{l}-0.245^{\star * *} \\
(0.062)\end{array}$ \\
\hline Single & $\begin{array}{l}-0.120^{* *} \\
(0.054)\end{array}$ & $\begin{array}{l}-0.241^{* * *} \\
(0.055)\end{array}$ \\
\hline Children & $\begin{array}{l}0.051^{* *} \\
(0.021)\end{array}$ & $\begin{array}{l}0.090^{* * *} \\
(0.024)\end{array}$ \\
\hline South & $\begin{array}{l}0.088 \\
(0.083)\end{array}$ & $\begin{array}{l}0.233^{* * *} \\
(0.082)\end{array}$ \\
\hline Centre & $\begin{array}{l}0.184^{* *} \\
(0.088)\end{array}$ & $\begin{array}{l}0.255^{\star \star \star} \\
(0.088)\end{array}$ \\
\hline NorthWest & $\begin{array}{l}0.135 \\
(0.101)\end{array}$ & $\begin{array}{l}0.026 \\
(0.101)\end{array}$ \\
\hline NorthEast & $\begin{array}{l}0.090 \\
(0.093)\end{array}$ & $\begin{array}{l}0.224^{* \star} \\
(0.095)\end{array}$ \\
\hline Wales & $\begin{array}{l}0.275^{\star \star *} \\
(0.095)\end{array}$ & $\begin{array}{l}0.127 \\
(0.088)\end{array}$ \\
\hline
\end{tabular}




\begin{tabular}{|c|c|c|}
\hline Scotland/N.Ireland & $\begin{array}{l}0.044 \\
(0.087)\end{array}$ & $\begin{array}{l}0.110 \\
(0.083)\end{array}$ \\
\hline Income & $\begin{array}{l}0.271 \\
(0.246)\end{array}$ & $\begin{array}{l}0.009 \\
(0.124)\end{array}$ \\
\hline 1991 & $\begin{array}{l}-1.279 \\
(1.505)\end{array}$ & $\begin{array}{l}-1.345 \\
(1.438)\end{array}$ \\
\hline 1992 & $\begin{array}{l}-1.185 \\
(1.485)\end{array}$ & $\begin{array}{l}-0.841 \\
(1.418)\end{array}$ \\
\hline 1993 & $\begin{array}{l}-0.648 \\
(0.698)\end{array}$ & $\begin{array}{l}-0.283 \\
(0.668)\end{array}$ \\
\hline 1994 & $\begin{array}{l}-0.447 \\
(0.638)\end{array}$ & $\begin{array}{l}-0.569 \\
(0.614)\end{array}$ \\
\hline 1995 & $\begin{array}{l}-0.589 \\
(0.732)\end{array}$ & $\begin{array}{l}-0.530 \\
(0.700)\end{array}$ \\
\hline 1996 & $\begin{array}{l}-0.222 \\
(0.350)\end{array}$ & $\begin{array}{l}-0.185 \\
(0.334)\end{array}$ \\
\hline 1997 & $\begin{array}{l}-0.129 \\
(0.422)\end{array}$ & $\begin{array}{l}-0.246 \\
(0.404)\end{array}$ \\
\hline 1998 & $\begin{array}{l}-0.761 \\
(0.827)\end{array}$ & $\begin{array}{l}-0.619 \\
(0.792)\end{array}$ \\
\hline 1999 & $\begin{array}{l}-0.417 \\
(0.392)\end{array}$ & $\begin{array}{l}-0.423 \\
(0.376)\end{array}$ \\
\hline 2000 & $\begin{array}{l}-0.636 \\
(0.726)\end{array}$ & $\begin{array}{l}-0.617 \\
(0.698)\end{array}$ \\
\hline 2001 & $\begin{array}{l}-0.338 \\
(0.373)\end{array}$ & $\begin{array}{l}-0.124 \\
(0.361)\end{array}$ \\
\hline 2003 & $\begin{array}{l}0.117 \\
(0.296)\end{array}$ & $\begin{array}{l}0.250 \\
(0.286)\end{array}$ \\
\hline 2004 & $\begin{array}{l}0.038 \\
(0.126)\end{array}$ & $\begin{array}{l}0.093 \\
(0.126)\end{array}$ \\
\hline 2005 & $\begin{array}{l}0.025 \\
(0.080)\end{array}$ & $\begin{array}{l}0.086 \\
(0.083)\end{array}$ \\
\hline 2006 & $\begin{array}{l}0.060 \\
(0.202)\end{array}$ & $\begin{array}{l}0.155 \\
(0.197)\end{array}$ \\
\hline Constant & $\begin{array}{l}1.526 \\
(4.271)\end{array}$ & $\begin{array}{l}4.046 \\
(4.054)\end{array}$ \\
\hline Observations & 41585 & 45616 \\
\hline
\end{tabular}

Source: Own calculations based on the BHPS

Note: Standard errors in parenthesis. Significance is denoted by: ${ }^{* * *} p<0.01,{ }^{* *} p<0.05,{ }^{*} p<0.1$.

Figure 4 plots the trends in changes in employment status, i.e. from no unemployment into positive spells in two consecutive years by gender. It can be observed that a higher proportion of men experienced a change in labour market status compared to 
women, although the gender gap is small except in the early 1990s. During the recession years, a high proportion of men and women experienced a change in status. Following the recession years, the gender gap in transition is small but clearly a higher proportion of men are likely to experience unemployment after being employed in the previous year relative to women. As the economy picked up, the figure shows fewer workers experiencing job losses and narrowing gender gap in changes in economic activity.

Figure 4. Zero into positive unemployment spells

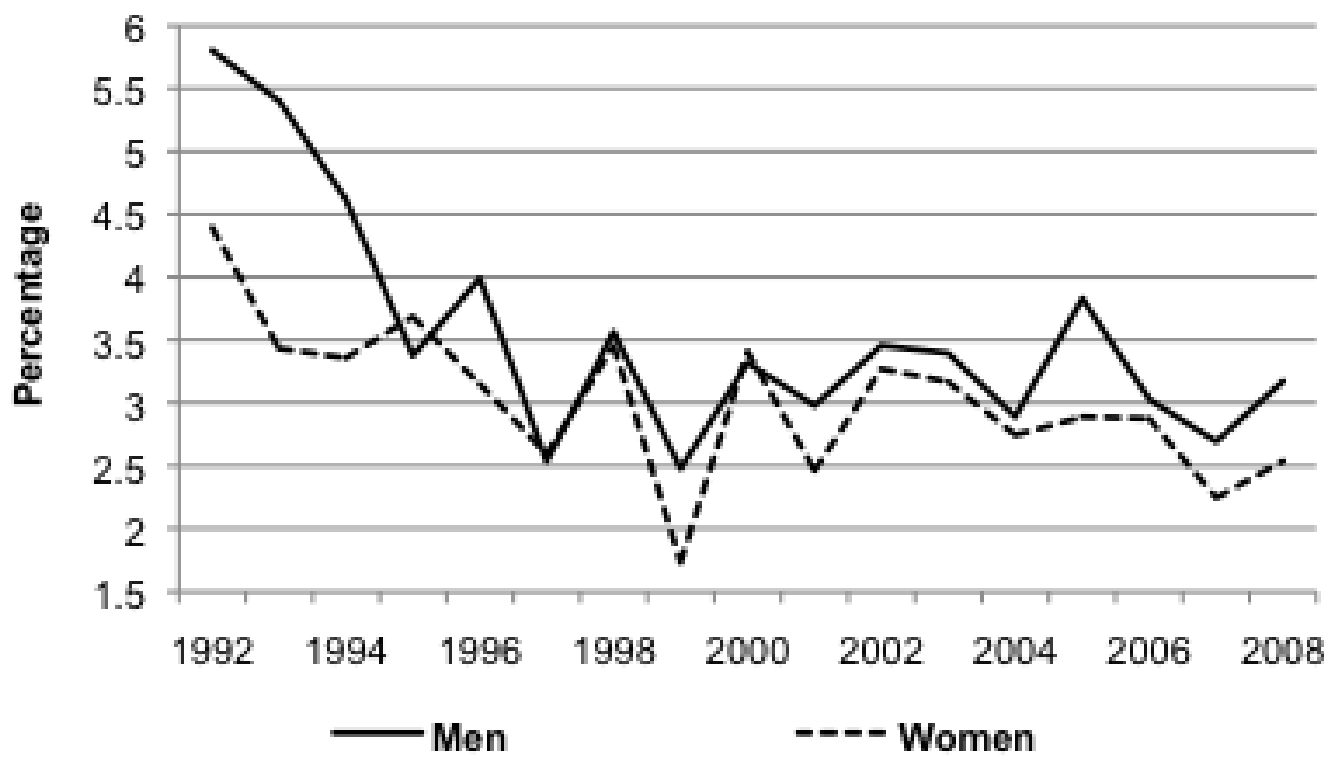

Source: Own calculation based on the BHPS

In summary, the empirical analysis of the transitional variables suggest that frequent changes in economic activity reflects job instabilities and cannot be ignored in understanding the welfare pattern of British men and women. The results show that switching from employment-unemployment-employment in consecutive years has a stronger negative effect on current job satisfaction of female workers, indicating that job instabilities hurt women more than men, although fewer women than men experience such instabilities throughout the survey period. And finally, frequent changes in economic activity have a stronger impact than the scarring effect of unemployment on wellbeing for men. As mentioned earlier, aggregate unemployment rates in Britain surged during the recession and male unemployment substantially rose. Furthermore, a nation's joblessness rate affects the welfare of both employed and unemployed workers (Clark et al., 2010). Britain's high unemployment rate in the early 1990's especially among men is also accountable for low job satisfaction scores. As the economic climate improved, the creation of jobs and better labour market prospects enhanced wellbeing of workers, especially among men. 


\subsection{Is welfare cyclical?}

To see the effect of the recession, the results control for interaction of changes in economic activity, such as having no spells in unemployment to positive spells with the recession years. Secondly, the effect of past spells in unemployment is interacted with recession years and is estimated for both men and women. The results are shown in Table 6 using logit regression technique. The net effect of instabilities in economic activity, i.e. switching from employment-unemployment-employment continues to affect women more than men, even during the recession. Thus, job satisfaction for both men and women is reduced by changes in economic activity, but the effect is stronger for women, regardless of the recession. And the probability of reporting high job satisfaction scores during the recession years is lower for workers that experienced spells in unemployment prior to current employment. Men are more dissatisfied with their current job after a period of unemployment than women. This implies that psychological imprints of unemployment are stronger for male workers than female workers, even in the recession years.

\begin{tabular}{|c|c|c|c|c|}
\hline $\begin{array}{l}\text { Table 6: Estimated } \\
\text { parameters from logit } \\
\text { regression }\end{array}$ & & & & \\
\hline High job satisfaction & Men & Women & Men & Women \\
\hline Recession years & $\begin{array}{l}-0.161^{\star \star *} \\
(0.056)\end{array}$ & $\begin{array}{l}-0.056 \\
(0.062)\end{array}$ & $\begin{array}{l}0.133^{* *} \\
(0.058)\end{array}$ & $\begin{array}{l}-0.066 \\
(0.063)\end{array}$ \\
\hline $\begin{array}{l}\text { Recession*zero into } \\
\text { positive unemployment }\end{array}$ & $\begin{array}{l}-0.171 \\
(0.223)\end{array}$ & $\begin{array}{l}0.276 \\
(0.257)\end{array}$ & & \\
\hline $\begin{array}{l}\text { Zero to positive } \\
\text { unemployment spells }\end{array}$ & $\begin{array}{l}-0.175^{\star *} \\
(0.083)\end{array}$ & $\begin{array}{l}-0.325^{* * \star} \\
(0.089)\end{array}$ & & \\
\hline $\begin{array}{l}\text { Recession } \\
\text { years*unemployment spell }\end{array}$ & & & $\begin{array}{l}-0.217^{\star} \\
(0.129)\end{array}$ & $\begin{array}{l}0.263 \\
(0.165)\end{array}$ \\
\hline Unemployment spell & & & $\begin{array}{l}0.145^{* *} \\
(0.057)\end{array}$ & $\begin{array}{l}-0.210^{\star \star \star} \\
(0.068)\end{array}$ \\
\hline MSc/Phds & $\begin{array}{l}0.077 \\
(0.117)\end{array}$ & $\begin{array}{l}-0.353^{* * \star} \\
(0.132)\end{array}$ & $\begin{array}{l}0.077 \\
(0.117)\end{array}$ & $\begin{array}{l}-0.351^{* * *} \\
(0.132)\end{array}$ \\
\hline University first degree & $\begin{array}{l}-0.143^{* *} \\
(0.066)\end{array}$ & $\begin{array}{l}-0.289^{* * \star} \\
(0.062)\end{array}$ & $\begin{array}{l}- \\
0.140^{* *} \\
(0.066)\end{array}$ & $\begin{array}{l}-0.288^{\star * *} \\
(0.062)\end{array}$ \\
\hline Vocational & $\begin{array}{l}-0.066 \\
(0.077)\end{array}$ & $\begin{array}{l}- \\
0.154^{\star \star} \\
(0.076)\end{array}$ & $\begin{array}{l}-0.065 \\
(0.077)\end{array}$ & $\begin{array}{l}-0.155^{\star *} \\
(0.076)\end{array}$ \\
\hline No qualification & $\begin{array}{l}0.155^{\star *} \\
(0.063)\end{array}$ & $\begin{array}{l}0.007 \\
(0.065)\end{array}$ & $\begin{array}{l}0.158^{* *} \\
(0.063)\end{array}$ & $\begin{array}{l}0.008 \\
(0.065)\end{array}$ \\
\hline Year of birth & $\begin{array}{l}0.014^{\star \star \star} \\
(0.004)\end{array}$ & $\begin{array}{l}0.006 \\
(0.004)\end{array}$ & $0.014^{\star \star}$ & $\begin{array}{l}0.006 \\
(0.004)\end{array}$ \\
\hline
\end{tabular}




\begin{tabular}{|c|c|c|c|c|}
\hline & & & $(0.004)$ & \\
\hline Year of birth squared & $\begin{array}{l}-0.020 \\
(0.108)\end{array}$ & $\begin{array}{l}- \\
0.270^{\star *} \\
(0.116)\end{array}$ & $\begin{array}{l}-0.015 \\
(0.108)\end{array}$ & $\begin{array}{l}-0.270^{\star \star} \\
(0.116)\end{array}$ \\
\hline UK born & $\begin{array}{l}0.432^{* * *} \\
(0.137)\end{array}$ & $\begin{array}{l}0.062 \\
(0.142)\end{array}$ & $\begin{array}{l}0.430^{* \star} \\
(0.137)\end{array}$ & $\begin{array}{l}0.050 \\
(0.142)\end{array}$ \\
\hline Small firm & $\begin{array}{l}0.227^{* * *} \\
(0.038)\end{array}$ & $\begin{array}{l}0.255^{\star \star} \\
* \\
(0.038)\end{array}$ & $\begin{array}{l}0.229^{* *} \\
* \\
(0.038)\end{array}$ & $\begin{array}{l}0.255^{\star \star \star} \\
(0.038)\end{array}$ \\
\hline Working hours & $\begin{array}{l}-0.231^{\star \star \star} \\
(0.073)\end{array}$ & $\begin{array}{l}-0.261^{* * *} \\
(0.045)\end{array}$ & $\begin{array}{l}-0.237^{* * *} \\
(0.073)\end{array}$ & $\begin{array}{l}-0.261^{\star \star \star} \\
(0.045)\end{array}$ \\
\hline Manager & $\begin{array}{l}0.612^{\star \star *} \\
(0.083)\end{array}$ & $\begin{array}{l}0.318^{\star \star *} \\
(0.089)\end{array}$ & $\begin{array}{l}0.605^{* *} \\
(0.083)\end{array}$ & $\begin{array}{l}0.316^{* * *} \\
(0.089)\end{array}$ \\
\hline Professional & $\begin{array}{l}0.533^{* * *} \\
(0.099)\end{array}$ & $\begin{array}{l}0.185^{\star} \\
(0.099)\end{array}$ & $\begin{array}{l}0.526^{* *} \\
* \\
(0.099)\end{array}$ & $\begin{array}{l}0.183^{*} \\
(0.099)\end{array}$ \\
\hline Technical & $\begin{array}{l}0.580^{\star \star \star} \\
(0.089)\end{array}$ & $\begin{array}{l}0.325^{\star *} \\
(0.091)\end{array}$ & $\begin{array}{l}0.573^{* \star} \\
(0.089)\end{array}$ & $\begin{array}{l}0.324^{* * *} \\
(0.091)\end{array}$ \\
\hline Clerical & $\begin{array}{l}-0.078 \\
(0.084)\end{array}$ & $\begin{array}{l}0.113 \\
(0.078)\end{array}$ & $\begin{array}{l}-0.079 \\
(0.084)\end{array}$ & $\begin{array}{l}0.112 \\
(0.078)\end{array}$ \\
\hline Craft & $\begin{array}{l}0.331^{* * *} \\
(0.080)\end{array}$ & $\begin{array}{l}0.179 \\
(0.123)\end{array}$ & $\begin{array}{l}0.327^{* *} \\
* \\
(0.080)\end{array}$ & $\begin{array}{l}0.179 \\
(0.123)\end{array}$ \\
\hline Personal & $\begin{array}{l}0.253^{* \star \star} \\
(0.098)\end{array}$ & $\begin{array}{l}0.368^{* *} \\
(0.079)\end{array}$ & $\begin{array}{l}0.249^{* *} \\
(0.098)\end{array}$ & $\begin{array}{l}0.366^{\star \star \star} \\
(0.079)\end{array}$ \\
\hline Sales & $\begin{array}{l}0.149 \\
(0.093)\end{array}$ & $\begin{array}{l}-0.019 \\
(0.084)\end{array}$ & $\begin{array}{l}0.144 \\
(0.093)\end{array}$ & $\begin{array}{l}-0.020 \\
(0.084)\end{array}$ \\
\hline Plant and machinery & $\begin{array}{l}0.026 \\
(0.079)\end{array}$ & $\begin{array}{l}-0.175^{*} \\
(0.105)\end{array}$ & $\begin{array}{l}0.025 \\
(0.079)\end{array}$ & $\begin{array}{l}-0.176^{*} \\
(0.105)\end{array}$ \\
\hline Promotion & $\begin{array}{l}0.651^{\star \star \star} \\
(0.035)\end{array}$ & $\begin{array}{l}0.511^{* *} \\
* \\
(0.035)\end{array}$ & $\begin{array}{l}0.648^{* *} \\
* \\
(0.035)\end{array}$ & $\begin{array}{l}0.511^{* * *} \\
(0.035)\end{array}$ \\
\hline Job tenure & $\begin{array}{l}-0.010^{\star \star \star} \\
(0.003)\end{array}$ & $\begin{array}{l}-0.014^{\star \star \star} \\
(0.004)\end{array}$ & $\begin{array}{l}-0.011^{* * \star} \\
(0.003)\end{array}$ & $\begin{array}{l}-0.014^{\star * *} \\
(0.004)\end{array}$ \\
\hline Second job & $\begin{array}{l}-0.080 \\
(0.059)\end{array}$ & $\begin{array}{l}-0.036 \\
(0.054)\end{array}$ & $\begin{array}{l}-0.080 \\
(0.059)\end{array}$ & $\begin{array}{l}-0.038 \\
(0.054)\end{array}$ \\
\hline Civil service & $\begin{array}{l}-0.101 \\
(0.097)\end{array}$ & $\begin{array}{l}-0.142 \\
(0.101)\end{array}$ & $\begin{array}{l}-0.100 \\
(0.097)\end{array}$ & $\begin{array}{l}-0.141 \\
(0.101)\end{array}$ \\
\hline Local government & $\begin{array}{l}0.192^{* *} \\
(0.078)\end{array}$ & $\begin{array}{l}0.214^{* *} \\
(0.059)\end{array}$ & $\begin{array}{l}0.193^{* *} \\
(0.078)\end{array}$ & $\begin{array}{l}0.214^{\star * *} \\
(0.059)\end{array}$ \\
\hline Other public & $\begin{array}{l}0.201^{* *} \\
(0.096)\end{array}$ & $\begin{array}{l}0.283^{* *} \\
* \\
(0.070)\end{array}$ & $\begin{array}{l}0.200^{* *} \\
(0.096)\end{array}$ & $\begin{array}{l}0.282^{\star \star \star} \\
(0.070)\end{array}$ \\
\hline
\end{tabular}




\begin{tabular}{|c|c|c|c|c|}
\hline Non profit & $\begin{array}{l}0.457^{* * *} \\
(0.163)\end{array}$ & $\begin{array}{l}0.244^{* *} \\
* \\
(0.086)\end{array}$ & $\begin{array}{l}0.460^{* \star} \\
(0.163)\end{array}$ & $\begin{array}{l}0.244^{\star * *} \\
(0.086)\end{array}$ \\
\hline No health problems & $\begin{array}{l}0.282^{* * *} \\
(0.034)\end{array}$ & $\begin{array}{l}0.340^{* *} \\
* \\
(0.034)\end{array}$ & $\begin{array}{l}0.281^{* *} \\
* \\
(0.034)\end{array}$ & $\begin{array}{l}0.340^{\star * *} \\
(0.034)\end{array}$ \\
\hline Age & $\begin{array}{l}-0.053^{* * *} \\
(0.015)\end{array}$ & $\begin{array}{l}- \\
0.035^{\star *} \\
(0.015)\end{array}$ & $\begin{array}{l}-0.055^{\star \star \star} \\
(0.015)\end{array}$ & $\begin{array}{l}-0.035^{\star *} \\
(0.015)\end{array}$ \\
\hline Age-squared & $\begin{array}{l}0.001^{* * *} \\
(0.000)\end{array}$ & $\begin{array}{l}0.001^{* *} \\
(0.000)\end{array}$ & $\begin{array}{l}0.001^{* *} \\
(0.000)\end{array}$ & $\begin{array}{l}0.001^{\star \star \star} \\
(0.000)\end{array}$ \\
\hline Separated & $\begin{array}{l}0.040 \\
(0.086)\end{array}$ & $\begin{array}{l}-0.242^{\star \star \star} \\
(0.062)\end{array}$ & $\begin{array}{l}0.043 \\
(0.086)\end{array}$ & $\begin{array}{l}-0.241^{\star \star *} \\
(0.062)\end{array}$ \\
\hline Single & $\begin{array}{l}-0.115^{\star \star} \\
(0.054)\end{array}$ & $\begin{array}{l}-0.239^{\star * \star} \\
(0.055)\end{array}$ & $\begin{array}{l}- \\
0.113^{* *} \\
(0.054)\end{array}$ & $\begin{array}{l}-0.238^{\star * *} \\
(0.055)\end{array}$ \\
\hline Children & $\begin{array}{l}0.049^{\star *} \\
(0.021)\end{array}$ & $\begin{array}{l}0.089^{* *} \\
(0.024)\end{array}$ & $\begin{array}{l}0.050^{* *} \\
(0.021)\end{array}$ & $\begin{array}{l}0.089^{\star \star *} \\
(0.024)\end{array}$ \\
\hline South & $\begin{array}{l}0.084 \\
(0.084)\end{array}$ & $\begin{array}{l}0.228^{* *} \\
* \\
(0.082)\end{array}$ & $\begin{array}{l}0.082 \\
(0.084)\end{array}$ & $\begin{array}{l}0.228^{* * *} \\
(0.082)\end{array}$ \\
\hline Centre & $\begin{array}{l}0.185^{\star *} \\
(0.088)\end{array}$ & $\begin{array}{l}0.252^{* \star} \\
* \\
(0.088)\end{array}$ & $\begin{array}{l}0.184^{\star *} \\
(0.089)\end{array}$ & $\begin{array}{l}0.253^{\star \star \star} \\
(0.087)\end{array}$ \\
\hline NorthWest & $\begin{array}{l}0.130 \\
(0.101)\end{array}$ & $\begin{array}{l}0.023 \\
(0.100)\end{array}$ & $\begin{array}{l}0.129 \\
(0.101)\end{array}$ & $\begin{array}{l}0.025 \\
(0.100)\end{array}$ \\
\hline NorthEast & $\begin{array}{l}0.091 \\
(0.094) \\
\end{array}$ & $\begin{array}{l}0.222^{* \star} \\
(0.095)\end{array}$ & $\begin{array}{l}0.090 \\
(0.094)\end{array}$ & $\begin{array}{l}0.223^{* *} \\
(0.095)\end{array}$ \\
\hline Wales & $\begin{array}{l}0.267^{\star \star \star} \\
(0.094)\end{array}$ & $\begin{array}{l}0.120 \\
(0.088)\end{array}$ & $\begin{array}{l}0.266^{* *} \\
* \\
(0.094)\end{array}$ & $\begin{array}{l}0.122 \\
(0.088)\end{array}$ \\
\hline Scotland/N.Ireland & $\begin{array}{l}0.033 \\
(0.087)\end{array}$ & $\begin{array}{l}0.105 \\
(0.083)\end{array}$ & $\begin{array}{l}0.031 \\
(0.087)\end{array}$ & $\begin{array}{l}0.106 \\
(0.083)\end{array}$ \\
\hline Income & $\begin{array}{l}0.273 \\
(0.248)\end{array}$ & $\begin{array}{l}0.011 \\
(0.125)\end{array}$ & $\begin{array}{l}0.280 \\
(0.249)\end{array}$ & $\begin{array}{l}0.010 \\
(0.125)\end{array}$ \\
\hline Constant & $\begin{array}{l}-0.137 \\
(0.588)\end{array}$ & $\begin{array}{l}1.570^{* *} \\
* \\
(0.558)\end{array}$ & $\begin{array}{l}-0.070 \\
(0.590)\end{array}$ & $\begin{array}{l}1.603^{\star * \star} \\
(0.559)\end{array}$ \\
\hline Observations & 41579 & 45614 & 41579 & 45614 \\
\hline
\end{tabular}

Source: Own calculations based on the BHPS

Note: Standard errors in parenthesis. Significance is denoted by: ${ }^{* * *} p<0.01,{ }^{* *} p<0.05,{ }^{*} p<0.1$.

Thus, there are implications of an economic boom or bust on wellbeing of workers. Men suffer more due to stalling unemployment during an economic downturn. And although the contribution of convergence in unemployment rates to the convergence 
in job satisfaction between men and women is very small, unemployment is shown to be a factor responsible for the convergence in job satisfaction between men and women. The effect of business cycles on welfare is stronger for male workers.

\section{Conclusion}

This paper investigates the gender gap in job utility of British workers from 1991-2008. There is evidence that male workers are catching up to women's welfare, resulting in narrowing the gap in utility from work reported by British workers. The results show that unemployment has a small contribution to the emerging pattern. Furthermore, frequent changes in economic status cannot be ignored in understanding patterns in job utility. And finally men benefit in the booming period and are worse off during an economic downturn.

\section{References}

Bardasi, E. and Francesconi, F. (2004) The impact of atypical employment on individual wellbeing: evidence from a panel of British workers, Social Science and Medicine, $58,1671-88$

Benz, M. and Frey, B. (2008) Being independent is a great thing: subjective evaluations on self-employment and hierarchy, Economica, 75, 362-83.

Bell, D. and Blanchflower, D. (2010) UK unemployment in the great recession, National Institute of Economic Review, 214 (1), R3-25.

Bell, D. and Blanchflower, D. (2011) Young people and the great recession, Oxford Review of Economic Policy, 27, 241-67.

Blanchflower, D. and Oswald, A. (1994) Estimating a wage curve for Britain, Economic Journal, 104, 1025-43.

Blanchflower, D. and Oswald, A. (2004) Well-being over time in Britain and the USA, Journal of Public Economics, 88, 1359-86. 
Blundell, R., Dearden, L., Goodman, A. and Reed, H. (2000) The returns to higher education in Britain: evidence from a British cohort, The Economic Journal, 110, F82-99.

Blundell, R., Meghir, C., Dias, A.C. and Reenen, J.V. (2004) Evaluating the employment impact of a mandatory job search program, Journal of the European Economic Association, 2, 569-606.

Booth, A. and Van Ours, J. (2008) Job satisfaction and family happiness: the part-time work puzzle, The Economic Journal, 118, F77-99.

Cameron, A.C. and Trivedi, P.K. (2005) Microeconometrics - Methods and Applications, Cambridge University Press, Cambridge/New York.

Clark, A. and Oswald, A. (1994) Unhappiness and unemployment, The Economic Journal, $104,648-59$.

Clark, A. (1996) Job satisfaction in Britain, British Journal of Industrial Relations, 34,189-217.

Clark, A. and Oswald, A. (1996) Satisfaction and comparison income, Journal of Public Economics, 61, 359-81.

Clark, A., Oswald, A. and Warr, P. (1996) Is job satisfaction U-shaped in age?, Journal of occupational and Organizational Psychology, 69, 57-81.

Clark, A. (1997) Job satisfaction and gender: why are women so happy at work?, Labour Economics, 4, 341-72.

Clark, A., Georgellis, Y. and Stanfey, P. (2001) Scarring: the psychological impact of past unemployment, Economica, 68, 221-41.

Clark, A. (2003) Unemployment as a social norm: psychological evidence from panel data, Journal of Labour Economics, 21, 323-51.

Clark, A., Kristensen, N. and Westergard-Nielsen, N. (2009) Job satisfaction and co-worker 
wages: status or signal?, The Economic Journal, 119, 430-47.

Clark, A., Knabe, A. and Ratzel, S. (2010) Boon or bane? Others' unemployment, well-being and job insecurity, Labour Economics, 17, 52-61.

Chamberlain, G. (1980) Analysis of covariance with qualitative data, Review of Economic Studies, 47, 225-38.

Di Tella, R., MacCulloch, R. and Oswald, A. (2001) Preferences over inflation and unemployment: evidence from surveys of happiness, The American Economic Review, $91,335-41$

Di Tella, R., MacCulloch, R. and Oswald, A. (2003) The macroeconomics of happiness, The Review of Economics and Statistics, 85, 809-27.

Dorsett, R. (2006) The New Deal for young people: effect on the labour market status of young men, Labour Economics, 13, 405-422.

Freeman, R. (1978) Job satisfaction as an economic variable, The American Economic Review, 68, 135-41.

Frey, B. and Stutzer, A. (2002) What can economists learn from happiness research, Journal of Economic Literature, 40, 402-35.

Frijters, P., Haisken-DeNew, J. and Shields, M. (2004) Money does matter! Evidence from increasing real income and life satisfaction in East Germany following reunification, The American Economic Review, 94, 730-40.

Gemmell, N. (1997) Externalities to higher education: a review of the new growth literature, in National Committee of Inquiry into Higher Education (Dearing Committee), Higher Education in Learning Society, Norwich: HMSO.

Goldsmith, A., Veum, J. and Darity, W. (1996) The psychological impact of unemployment and 
joblessness, Journal of Socio-Economics, 25, 133-58.

Higher Education Statistics Agency (2013) The gender gap in universities, accessed at https://docs.google.com/spreadsheet/ccc?key=0Aq73qj3QsIDedDA0OTZHX0ZtXzZEUn d0SnNBciMyQIE\#gid=4 on January 21, 2013.

Idson, T. (1990) Establishment size, job satisfaction and the structure of work, Applied Economics, 22, 1007-18.

Knabe, A., Ratzel, S., Schob, R. and Weimann, J. (2010) Dissatisfied with life but having a good day: time use and wellbeing of the unemployed, The Economic Journal, 120, 86789.

Knabe, A. and Ratzel, S. (2011) Scarring or scaring? The psychological impact of past unemployment and future unemployment risk, Economica, 78, 283-93.

Levy-Garboua, L., Montmarquette, C. and Simonnet, V. (2007) Job satisfaction and quits, Labour Economics, 14, 251-68.

Oswald, A. (1997) Happiness and economic performance, The Economic Journal, 107, 181531.

The World Bank (2013) World development indicators, accessed at http://data.worldbank.org/data-catalog/world-development-indicators on January 20 2013.

Winkelmann, L. and Winkelmann, R. (1998) Why are the unemployed so unhappy? Evidence from panel data, Economica, 65, 1-16. 